Historic, Archive Document

Do not assume content reflects current scientific knowledge, policies, or practices. 



\section{SURPLUS STOCK.}

Below is a list of stock that we have in surplus and are offering at very low prices. It is stock that we can recommend beyond any question and is of exceptional value. You will find each variety priced under its proper head in catalogue:

RED RASPBERRY

HOUGHTON GOOSEBERRY

CLIMBING AND MOSS ROSES
CURRANTS A UERICAN ARBOR VITAE YORWAT SPRUCE
CATALPA SPECIOSA EUROPEAN WHITE ELY WHITE BIRCH

\section{Number of Trees or Plants Required Per Acre at the Following Distances.}

\begin{tabular}{|c|c|c|c|c|c|c|c|c|c|c|c|}
\hline $3 \mathrm{by}$ & 3 feet & $\ldots 4,800$ & trees & or & plants & 12 by 12 & & $\ldots .302$ & & & lan \\
\hline 4 by & $4 \quad 6$ & . 2,722 & 66 & 66 & 66 & 15 by 15 & 66 & . ..193 & 66 & 66 & 66 \\
\hline 5 by & 66 & $\ldots 1,741$ & 6 & 66 & 66 & 18 by 18 & 66 & ...134 & 66 & 66 & .6 \\
\hline $6 \mathrm{by}$ & 66 & $\ldots 1,210$ & 66 & 66 & 66 & 20 by 20 & 66 & . . 108 & 66 & 66 & 66 \\
\hline y 8 & 66 & .. 680 & 66 & 66 & 66 & 25 by 25 & 66 & .. 69 & 66 & 66 & 66 \\
\hline $10 \mathrm{by} 10$ & 66 & .. 435 & 66 & 66 & "6 & 30 by 30 & 66 & $\ldots 48$ & 66 & 66 & 66 \\
\hline
\end{tabular}

\section{Weight of Trees and Plants PACKED.}

Fruit Trees......5 to 7 feet, weight about $100 \mathrm{lbs}$. to 100 trees.

" " ......3 to 5 " " 25 to 50 1bs. per 100 trees.

Grape Vines, Currants, Goose-

berries, Blackberries, Red

Raspberries, Black Rasp-

berry Tips............... weight about 10 to $251 \mathrm{bs}$. to 100 plants.

Strawberry Plants........ ، " " " 20 to 25 " 1000 “

\section{CARE OF TREES WHEN RECEIVED.}

If trees are at all dried or shriveled place them at once in water, completely covering them for one or two days, then take and plant them out as desired.

\section{PLANTING.}

It is highly important that the holes be dug sufficiently large and deep to accommodate the roots without binding them up or cramping thiem. Place in the bottom two or three inches of fresh surface soil to bed the roots in; set the tree two or three inches deeper than it originally grew. Cut off all decayed or bruised roots; set the tree in the hole with the heaviest side or strongest $1 \mathrm{imbs}$ toward the southwest, and the tree leaning a little in that direction, to resist the strong winds from that source; straighten out a11 the roots carefully and cover with the finest and best surface soil, shaking the tree gently so that the roots will resume their natural position. When the hole is half full, if the ground is dry, pour in water sufficient to thoroughly dampen the earth, then fill up the hole, tramping very firmly, particularly around the stem to prevent the wind from loosening the tree and disturbing the roots and to prevent the air from penetrating to the roots. The surface should be left loose and mellow, to receive air and moisture. If planted in the spring, and the weather continues dry, moisture should be maintained by watering. In the fall, mulch or cover the ground for several feet around with coarse manure to the depth of five or six inches. Mulching is very essential for winter protection. Always loosen label wire when planted. 


\section{Augustine \& Co..}

NORMAL, ILL.

No..................

Forward to

Name of Person

(Ladies please sign Miss or Mrs.)

Name of Post Office.

Name of Express Office...

Name of County...

Name of State.

I hereby agree not to sell trees of the Sudduth Pear, nor propagate nor permit to be propagated, from the stock enumerated below, without a permit signed and sealed by Augustine \& Co. I further agree not to propagate and sell trees of the Sudduth Pear under any other name to avoid this agreement.

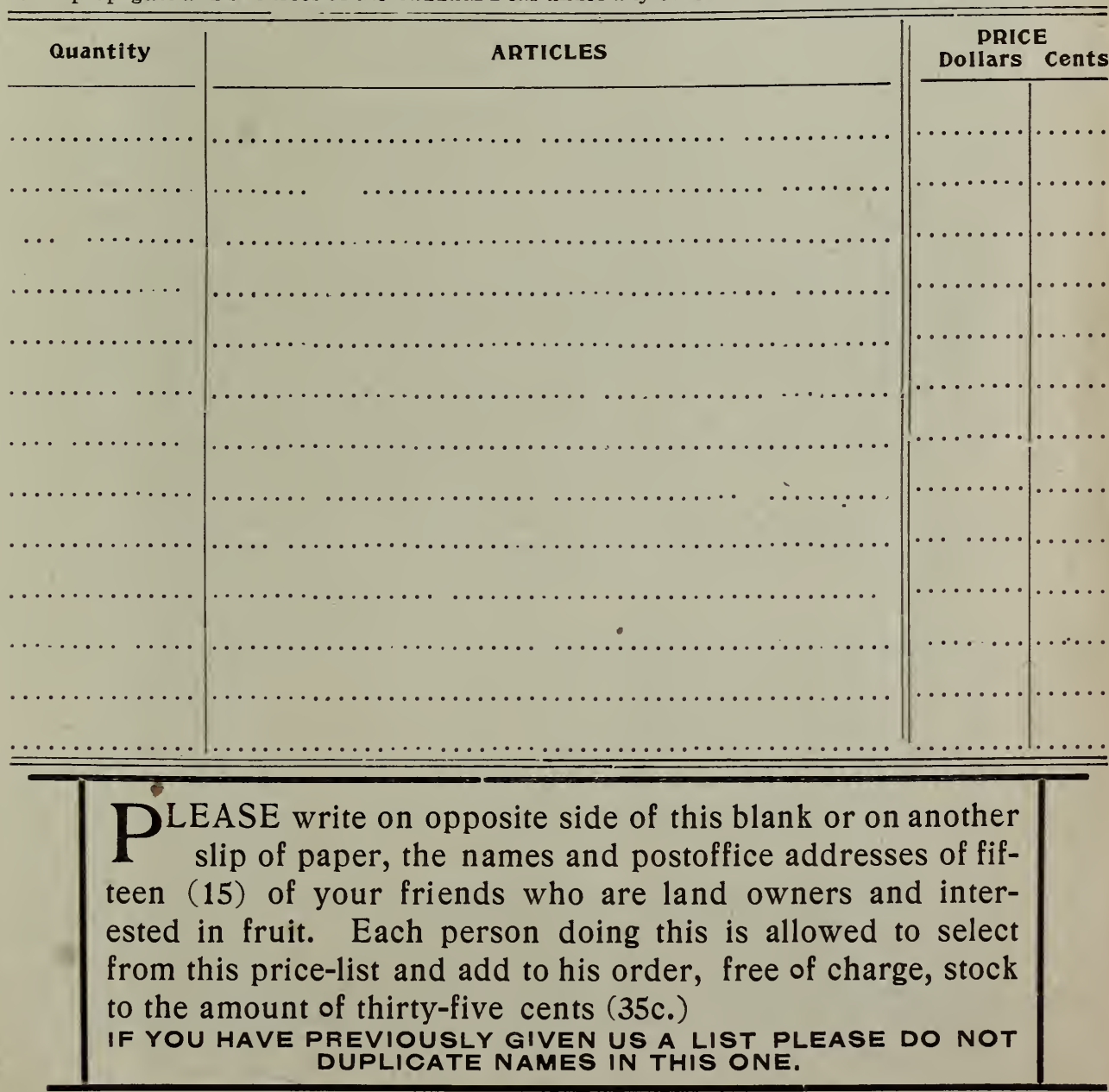




\section{ORDER SHEET.-Continued.}

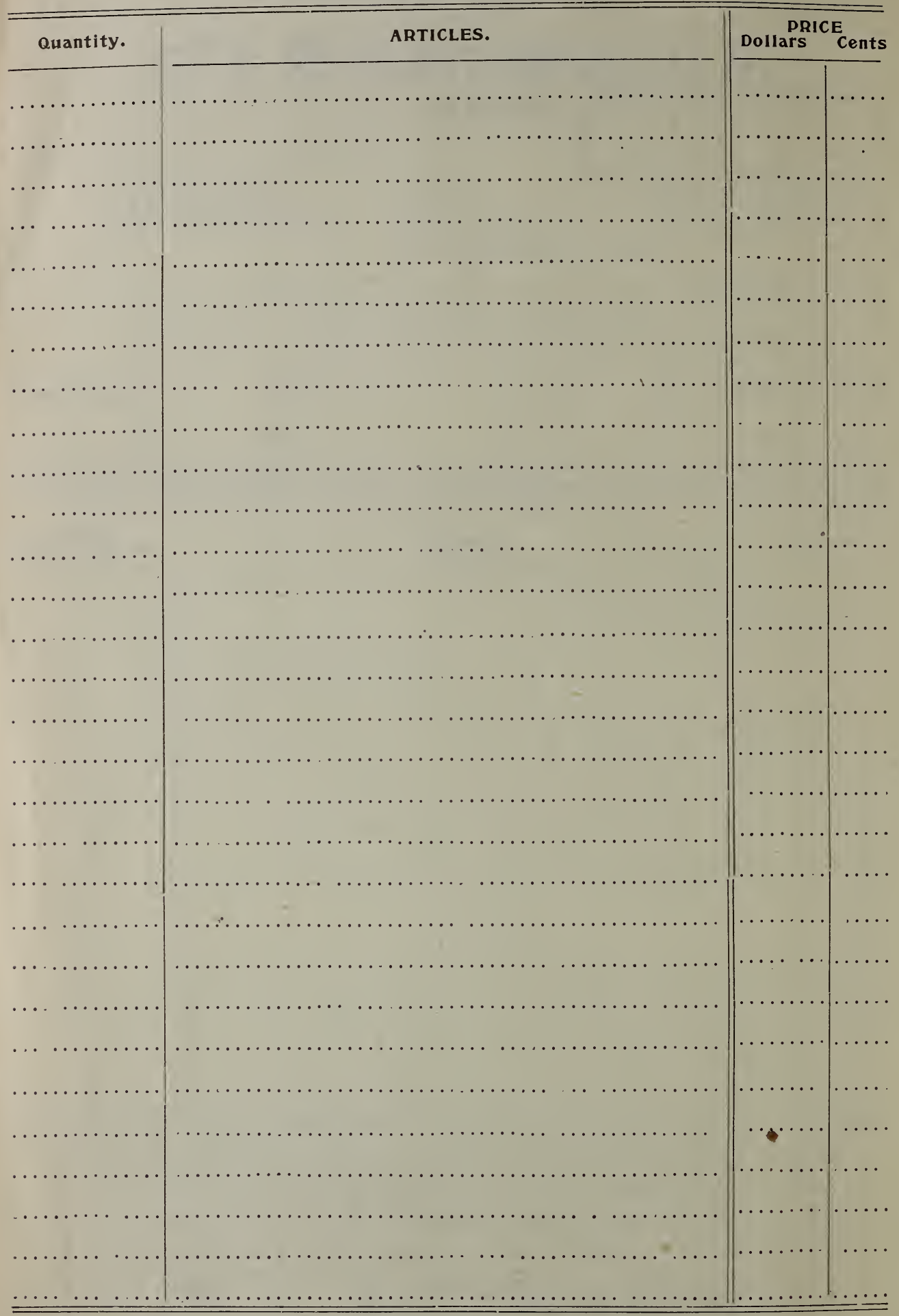




\section{A Business Talk.}

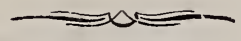

W

ITH this Twentieth Century issue of our price-list we desire to thank our many patrons for the liberal and increased patronage which they have accorded us. We greet you with our best wishes for a prosperous year. Our business has increased wonderfully, and at present there is a greater demand for all varieties of nursery stock than there has been for many years. The past year has been a phenomenal growing season, and we are in a position to supply our customers with a superior line of well-grown and well-rooted stock.

Correspondence.-We are always glad to answer any questions which our friends may ask. We have devoted nearly a life-time of energy, study and investigation to the needs of the planter. We are making it our business to give you the results of this experience, and we are a1ways ready and glad to offer any suggestions on the selection of varieties, planting and caring for the orchard.

We Have no Salesmen for General Nursery Stock.-We wish to emphasize this fact, and to say that orders sent directly to us will have our careful, personal attention, as it is our earnest desire to satisfy our customers. We have set out to protect the planter and to give him the benefit of wholesale prices. We have over 700 acres of orchards of our own planting. Besides this we have three trial and experimental plots, one in the South, one in the West, and one here at Normal, in which we are testing over 500 varieties of fruits. With this knowledge and experience we feel that we are in a position to render valuable aid alike to the average planter and commercial orchardist, and when the selection of varieties is left to us, as is often the case, we are prepared to furnish the best selection as demanded by different localities.

While we have a reputation for making a specialty of the Sudduth Pear, we are by no means neglecting other departments of our business. We are testing and pushing to the front every other desirable fruit and ornamental.

The prices we make you are for first-class stock in every particular, properly grown and properly handled and packed. We are not offering any cheap stock, or stock that we cannot thoroughly recommend, and our prices a re as reasonable as such stock can be grown and placed upon the market.

Our Location. We are located 125 miles southwest of Chicago, at Norma1, Illinois.

Our Facilities for Shipping are Unexcelled.-Bloomington and Normal are practically one city. We can ship in three directions on the Illinois Central, three on the Chicago and A1ton, and two each on the C., C., C. \& St. L. (Big Four) and Lake Erie and Western Railroads. By means of these roads and their branches, radiating in ten different direc tions, we make connection with every prominent trunk line in the 
country, and are thus enabled to forward shipments with great promptness. We can also ship by express to any point.

We have a thoroughly appointed office, managed according to the most approved current business methods. From a simple beginning in 1867 we have built up our business to its present gratifying proportions on thoroughly honest principles. We believe in fair and honorable dealing, and have always made things right with our customers, even if it necessitated a loss to ourselves.

We have a complete system of water-works on our packing grounds, whereby we are enabled to distribute water to every part of them. With our large nursery and orchard interests, our standing as horticulturists and with a pride that comes naturally from a prominent connection with the horticultural societies and experiment stations of the State, it has been our aim from the first to build on a solid foundation for the future rather than to do business on the principle "that we will make all we can in a few years and then step out and let our reputation take care of itself."

If our price list comes to you for the first time this year, we hope you will read it and not lay it aside. We respectfully solicit a trial order from you, at least, even if only a small one, for we are certain we can hold your custom to the benefit of both parties if you will only give us a chance.

$$
\text { Yours truly, }
$$

\section{AUGUSTINE \& CO.}

\section{TERMS, CONDITIONS AND SHIPPING.}

Special Low Express and Freight Rates.-By special arrangement we are now able to ship to our customers by any express line, to any part of the country, Trees, Plants, Bulbs, and all other Nursery Stock, at the hundred pounds merchandise rate, less a special reduction of twenty per cent therefrom.

Under our present western classification we are enabled to get a very low freight rate by releasing a11 stock at the valuation of $\$ 5.00$ per cwt.

Errors.-While exercising the utmost care in filling orders, usually doing more than we offer, accidental errors will sometimes occur in the press of business; prompt and satisfactory correction will be made when notified. Patrons are earnestly requested to keep copies of their orders for com parison. A11 claims must be made within ten days after receipt of stock.

Terms of payment.-Cash with order invariably. Remit us by draft on New York, Chicago, or St. Louis, Posta1 or Express Money Order, payable to the order of Augustine \& Co., or Registered Letter, or currency by express prepaid.

We will ship stock C. O. D. when desired, but C. O. D. orders must invariably be accompanied with a remittance for half the amount of the order. The Express and Railroad Companies hold us responsible for freight charges on a11 such shipments, hence our friends will recognize the necessity of this rule. Do not send personal checks unless you add 15 cents for collection. It costs us this amount to have them cashed.

Substitution.-It is our custom, should the supply of a variety be exhausted, (which will occasionally occur in our establishments) to substitute in its stead a similar sort or give the value of another grade of the variety named. When it is desired that we sha11 not do this, it must be so stated in the order. To simply affix the words "No Substitution" is all that is necessary. Whenever it is necessary to make substitution we give this matter our own personal supervision, no haphazard substitution under any circumstances.

Our Guarantee.-We warrant our stock true to name, with the express understanding that should any not prove so, we will replace it with other stock, but are not liable for damages beyond this. A sure indication of the purity of our stock is the fact that customers of former years continue to deal with us.

Trees and plants in Large Quantities and Special Varieties.-Estimates for such will be given on application. Orders for 100 or 1000 trees in the aggregate, but comprising several classes, will be billed as follows: 50 trees of a class at 100 rates; less than 50, at 10 rates; 500 at 1,000 rates; less than 500 , at 100 rates. 
packing Free.-We bear all expenses of packing, boxes, bales, etc., and personally see that the stock is put up in the most careful manner. Good packing pays us as well as our customers. We ship with flattering results to all points in the United States and to foreign countries.

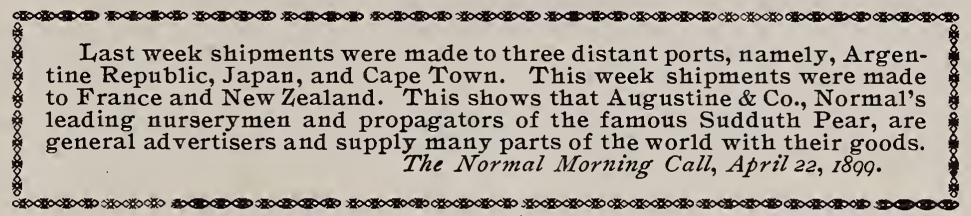

Shipping.-The fall shipping season opens about October 1 , and continues unti1 about December 15. Patrons are requested to give us explicit shipping directions. When these are not furnished we use our best judgment. It is our custom when sufficient time is given to obtain through express and freight rates for our customers. Our responsibility ceases after delivery of goods to the carriers. When losses occur or goods are damaged en route, claims should be filed against the carriers upon receipt of goods. A small number of plants or vines can be sent by mail safely. Any number of four pound packages can be sent to one address. Rate $8 \mathrm{c}$ per pound. In case mail shipment is desired remit sufficient to cover cost of postage.

Order Early.-The earlier the better. If you wish any more stock later such additional order can be filled at that time. If you can not send all of the money send a part, which will secure the booking of your order; the balance before shipment. Few people realize the enormous amount of labor that is crowded into a few weeks' time in the spring and fall for nurserymen and it is greatly to our advantage as we11 as to our customers' to have orders placed as early as possible. If your order is placed before the shipping season opens it gives us time to have everything prepared properly during the time we are not so busy, and we are better able to make calculations as to the amount of stock required for the season. We have decided $t_{\text {) }}$ offer discounts as noted below for all early orders, which will be quite a feature with our customers. It will save you money and us time to place your orders early.

\section{Discounts.}

On a11 orders for $\$ 5.00$ or over placed during the month of August, 6 per cent dis * count.

On a11 orders for $\$ 10.00$ and over placed during the month of August, 10 per cent discount.

On ail orders for $\$ 5.00$ and over placed during the month of September, 5 per cent discount.

On all orders for $\$ 10.00$ or over placed during the month of September, 8 per cent discount.

Cash must invariably accompany order to full amount when discount is a1lowed.

\section{FRUIT DEPARTMENT.}

\section{Apples.}

Astrachan Red-Large, roundish, near1y covered with deep crimsom, overspread with thick bloom; juicy, rich and beatifu1; good bearer; free. July.

Benoni-Medium, roundish, pale yellow, shaded with crimson; juicy, tender, subacid. August.

Duchess of Oldenburg-Russian, medium to large size; skin yellow, streaked with red and somewhat blushed, sometimes with a faint blue bloom; flesh juicy and good, with a rich sub-acid flavor; productive; slow. August.

Maiden's Blush-Rather large, oblate, smooth, regular, with a fine, even1y shaded red cheek or blush, on a clear, pale yellow ground; flesh white, tender sprightly, with a pleasant sub-acid flavor; bears large crops; free. August and September.

Fameuse-(Snow Apple).-Medium size, roundish, oblate; whitish ground, striped with deep red; flesh very white, juicy and pleasant. October and November.

Ben Davis-(New York Pippin).-Fruit medium to large, roundish; skin yellowish splashed and striped, and almost covered with red; flesh white, tender, moderately juicy, sub-acid; an excellent variety; tree very hardy, a free grower, coming into bearing early, and is very productive; it blooms late in the spring, thereby often escaping late frosts; very popular in the West and Southwest. December to March.

Iowa Blush-Medium in size, roundish, conicle, whitish, with red cheek; quality fine, tart; tree vigorous and hardy on the prairie. November to January.

Jonathan-Fruit medium, roundish, skin yellow, nearly covered with dark or lively red; fine grained, very tender, and finely flavored, mod. October to December. 


\title{
Apples.-Continued.
}

Minkler-Fruit medium, roundish, oblate, slight1y conicle, pale greenish yellow, striped and splashed with two shades of red, flesh yellowish, compact, moderately juicy, mild, pleasant, sub-acid; tree irregular grower; rig. January to A pril.

Missouri Pippin-Large, oblong, bright red, with numerous gray dots, very handsome, and of fair quality; an early and very abundant bearer, and very profitable orchard fruit; vig. December to March.

Northwestern Greening-A magnificent large, greenish, golden apple, late winter. very hardy even in Wisconsin and Minnesota, a strong healthy, upright grower; one of the very best; one of the few kinds to bear a crop in 1898, when the apple crop was a failure.

Pewauke--Medium to 1arge, roundish, somewhat flattened, bright yellow, streaked and spotted, with dark red, flesh white, tender, juicy, sub-acid; a seedling from the Duchess of O1denburg, and inherits its quality of extreme hardiness, which makes it a most reliable kind in cold climates. December and January.

Roman Stem-Fruit medium, whitish yellow, splashed with russet; flesh tender, juicy; rich, musky flavor; fine dessert apple; mod. November and December.

Wealthy-An apple of fine appearance and quality, an early and profuse bearer; a good market apple of its season; tree hardy; its chief fault is killing itself by its early and excessive bearing; in size and beauty it equals Baldwin and is a better dessert apple. Will bear when nearly all others fail.

\section{Other Varieties.}

Summer-E'y Harvest, Red June, Sops of Wine, Sweet June, E'y Ripe, Trenton Ear1y, E'y Strawberry, Summer Queen, Summer Rambo, Red Beitigheimer, Keswick Codlin, Yellow Transparent, etc.

Autumn-Colvert, Flora Bell, Rambo, Haas, Aut. Strawberry, Lansinberg, Fall Pippin, Twenty Ounce, Bailey's Sweet, etc.

Winter-Yellow Be11, Eng. Golden Russet, Baldwin, Mann, Janet, Grimes' Golden, Lawrer, Rock Pippin, King, Milam, White Winter Pearmain, Wine Sap, Tolman Sweet, Northern Spy, Wagner, Iowa Bush, Hubbard's Nonesuch, McIntosh Red, Minkler, Wolf River, Ark. Black, Gano, Willow Twig, Mam. Black Twig, York Imperia1, Huntsman's Favorite, Rome Beauty, Romanite, Clayton, Ingram, Winter Sweet Paradise and many other varieties.

4 to 5 feet, we11 branched, symmetrical, 2 and 3 years.............. EACH $10.15|\$ 1.30| \$ 12.50$

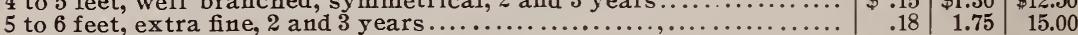

\section{Crab Apples.}

Our varieties comprise Whitney's No. 20, Martha, Quaker, Beauty, General Grant, Hyslop, Brown's Transcendent, etc.

$\begin{array}{lll}\text { EACH } 10 & 100\end{array}$

3 to 4 feet.............................................. $\$$.15 $\$ 1.20 \mid \$ 11.00$

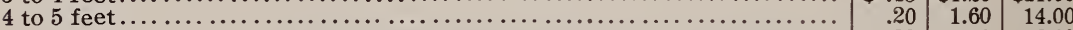

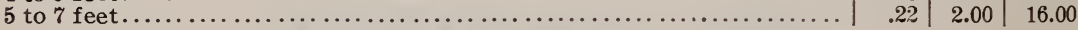

\section{Pears.}

Kieffer's Hybrid. This pear was raised from the seed of the Chinese Sand Pear accidentally crossed with the Bartlett or some other kind grown near it. Tree has large, dark green, glossy leaves, and is of itself very ornamenta1; is an ear1y and rery prolific bearer; the fruit is of good quality, wonderfully showy, and is valuable for the table and market; it never rots at the core. S. Vig. September and October.

Garber Hybrid.-A seedling of Chinese Sand Pear; very vigorous and comparatively free from blight; very productive; fruit large, round, handsome, smooth, waxy yellow; excellent for canning and preserving; for dessert it is a better pear than the Kieffer and very similar in every respect except it is not quite as long a keeper.

Bartlett.-Large size, with often a beautiful blush to the sun; buttery; very juicy and high flavored; bears early and abundantly; rery popular. Vig. August.

Seckel.-A delicious little russet pear, renowned for its rich juiciness; tree slow in growth.

Sheldon.-A nother excellent russet pear, of good size and flavor.

Other Varieties.-Comprising many of the leading sorts, such as Idaho, Flemish Beauty, Clapp's Favorite, Lawrence, Souvenir de Congress, Beurre de Anjou, Manning's Elizabeth, Duchess d'Angouleme, Longworth and others.

\section{Price of Pear Trees}

\author{
SUDDUTH PEAR.
}

(See back of book for description.) 


\section{Price of pear Trees.-Continued.}

LINCOLN PEAR.

EACH $10 \quad 100$

4 to 6 feet, 1 year, very thrifty $\ldots \ldots \ldots \ldots \ldots \ldots \ldots \ldots \ldots \ldots \ldots \ldots . \ldots \ldots .20|\$ 1.90| \$ 18.00$

KEIFFER PEAR.

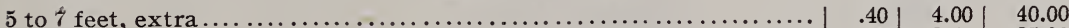

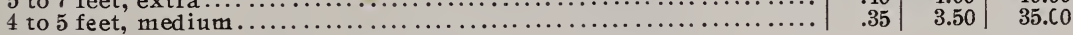

COMMION VARIETIES.

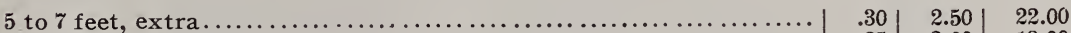

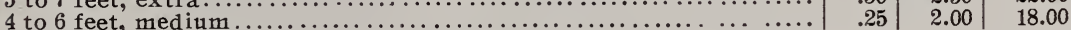

\section{THE LINCOLN PEAR.}

The Lincoln Pear has been one of our specialties for the last fifteen years. The increased demand for it from year to year has invariably taken nearly all of our oneyear stock, though each year we have increased our plant, sufficient, as we thought, to insure our getting out at least a reasonable amount of two-year trees. This year the demand has been so great that we can offer only one-year-old trees. These are very fine, however, four to six feet high and very thrifty. We are the original propagators of the Lincoln Pear, and had our attention first called to this remarkable fruit by Mr. Calvin Grapes, some fifteen years ago. The seed from which the original tree sprung was brought from Urbana, Ohio, by Mr. Grap s' mother-in-1aw in 1836, and after repeated urgings on the part of Mr. Grapes, who had known of the value of the tree for a great many years, our Mr. H. Augustine went to investigate it. From the wonderful vigor of the old tree, now over sixty-five years old, together with the fine appearance of the young bearing trees that Mr. Grapes had propagated and planted on his old farm, its remarkable bearing qualities, and the esteem in which the pear was held in the neighborhood by the old settlers, we were convinced that the tree certainly had merit. We had some time previous to this devoted much attention to seeking out a pear that was adapted to our prairie soil. The Lincoln from the first has continually gained favor and seems more strongly established in the favor of horticulturists than ever. We have bearing trees on our experimental grounds that we have watched from the time they were propagated. These and a great many others that we have obsersed in different 1ocalities seem to have the characteristics of the parent tree to a marked degree. The fruit which we exhibited at

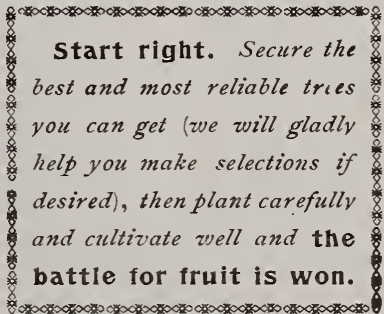
the Omaha Exposition created much interest.

The value of the Lincoln Pear lies in its comparative exemption fron: blight and disease, in its hardine-s and great productiveness, bearing from thirty to forty bushels of fruit in a season. The fruit is medium to large, with a rich aromatic flavor, core small and healthy, and the fruit has a very beautiful waxy appearance when fully ripe.

In the I1linois State Horticultural Experimental Station's report, the Lincoln is highly recommended aud was spoken of as one of the new fruits that has come to stay. It has shown less blight than any other variety except the Sudduth.

It seems to be genera11y conceded that in every line of business, articles of worth will be counterfeited, and unscrupulous men will deceive the people. We regret the Lincoln Pear has been no exception to this rule. One of many instances-two sears ago our Mr. Augustine went a long distance to see a Lincoln Pear orchard that was bearing its first crop of fruit. The unsuspecting farmer who had bought the trees at a high price some years ago was surprised to learn that he had a very fine Keiffer pear orchard. So much of this kind of work has been done that we have had our trade mark registered in the United States Patent Office, and we will GUARANTEE every tree leaving our grounds, BEARING OUR SEAL, TO BE GENUINE.

If you want the genuine Lincoln Pear and no mistake, see that it bears our registered sea 1 and trade mark.

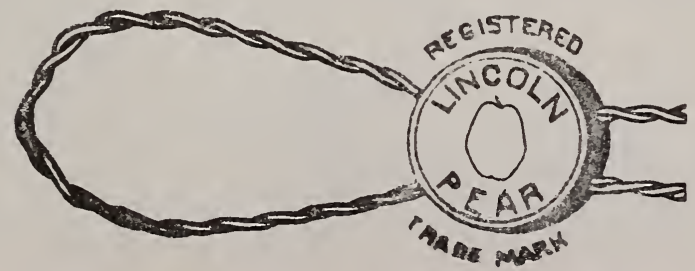

NOTE PARTICULARLY. The Lincoln is not the Lincoln Coreless, which is comparatively a worthless variety.

AUGUSTINE \& CO.,

Normal, lllinois. 


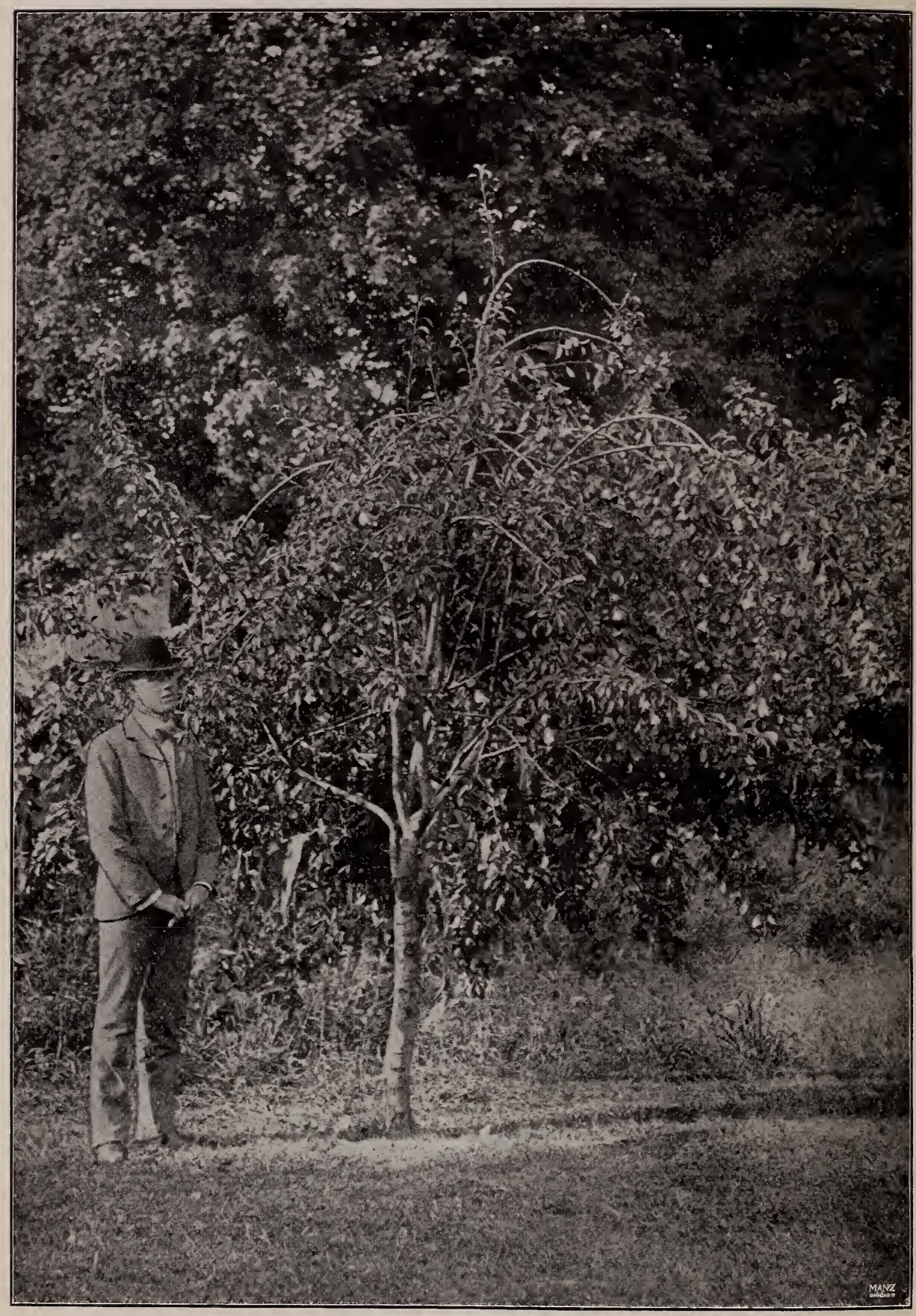

\section{A LINCOLN PEAR TREE IN BEARING.}

Five years old. Growing at the home of Mrs. Cora U. Gapen, Norma1, Illinois. Photographed, August 18, 1900. 


\section{Lincoln Pear--Continued.}

Messrs. Augustine \& Co., Normal, Ill.:

Lincoln, Ill., February 14, 1895.

GENTLEMEN:- In reply to your letter will say, that I have known the Lincoln Pear Tree, growing west of Lincoln, Inlinois, for over forty years, and believe $\mathrm{I} \mathrm{know}$ it as well as anyone now living, and can frankly say that its good qualities are so numerous and so apparent that I could find no fault, either with the tree or the fruit it bears, if I desired to. Too much cannot be said in praise of the tree and its fruit. I have lived near the tree for the past forty years, is why I speak with such confidence, and I would like to say better things for the pear if I knew how.

H. L. Pierce.

CoBDEN, ILL., January 1, 1895.

I have a number of trees growing of this variety-all I could get at one nnrseryand am well pleased with its rapid growth and freedom from disease. I have it in my own orchard and in the Illinois State Horticultura1 Society's Experimenta1 Station here, of which I have charge. The most careful watching has failed to discover blight on either limb or leaf. I have seen the tree in other parts of the state, but after the most rigid examination I could give them have never detected the presence of this disease.

I have tried all the "blight proof" varieties in years past, and find they a11 blight and die, except Lincoln and Sudduth. When the Lincoln was first brought to my notice, and for several years afterwards. I declined buying, and classed it with humbugs I had already tried. Repeated disappointments had destroyed my confidence in all pears. A more intimate acquaintance gives me more assurance, and I shall plant the Lincoln largely. Of the fruit I cannot speak so confidently, not being familiar with it. But men living in different parts of the state, of whom I have made diligent inquiry, and who know the fruit we11; a11 testif $v$ to its superior quality. Taking the Lincoln in all its good points, viz: good grower, good bearer, freedom from blight, good quality, and good looking fruit, I consider it one of the money-makers of the future.

T. E. GoodRICH, Pres. I11 State Horticultural Society.

\section{Cherries.}

Beyond question the most profitable and sure crop of any fruit for Central I1linois, entirely too much neglected. Common varieties have netted us $\$ 6.50$ per tree at six years of age.

\section{Varieties.}

The three standard varieties for the Mississippi Valley are:

1. Early Richmond-It is the old standby; a sure cropper, very hardy, abundant bearer, and the best of the sour sorts for family or market.

2. Mt. Morency-A bout 15 days later than the Early Richmond; similar to it in every way though; fruit is a trifle larger and more meaty; tree more vigorous.

3. Eng. Morello- This variety is among the finest of the late sorts where it can be grown successfully; subject, however, to wormy fruit and the rot.

Our list of varieties comprises:

Sour Varieties-Early Richmond, Mt. Morency, English Morello, Wragg (Russian), Ostheim (Russian).

Sweet Varieties-O1ivett, Dyehouse, May Duke, Empress Eugenie, Louis Phillip, Late Duke, Gov. Wood, Luelling, Reine Hortense, Napoleon and Yellow Spanish. ...\$ $.35|\$ 3.00| \$ 20.00$

Rocky Mountain Dwarf

SOUR VARIETIES.

5 to 6 feet, extra............................................ $\$ .40|\$ 3.50| \$ 30.00$

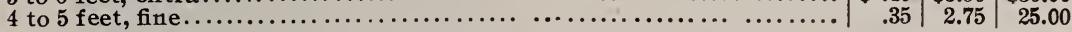

SWEET VARIETIES.

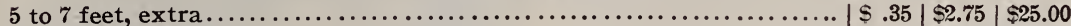

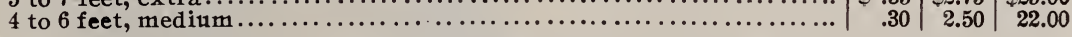

\section{Plums.}

Japanese Varieties.

Botan or Abundance-This remarkable plum is being catalog ued by some under the name of Abundance on account of its wonderful bearing qualities. It is one of the imported Japan varieties, the correct name being Botan. It is so remarkably strong and handsome in growth and foliage as to make it an ornament to any yard. It excels in early and profuse bearing. The fruit is 1arge, handsome, showy, and practically curculio proof; fruit beautiful lemon yellow ground, nearly overspread with bright cherry, and with a heavy
bloom; large to very large; oblong, tapering to the point; flesh orange yellow, meltSEE OUR
ORDER SHEET
AND SAVE MONEY ing, rich and highly perfumed. July.

Burbank-Another exceeding1y raluable sort that is proving a bonanza to a11 planters. A very vigorous grower, usually producing a crop second year after transplanting. Large; nearly globular, clear cherry red with a thin lilac bloom; flesh a deep yellow, very sweet, with a peculiar and very agreeable flavor. Hardy, one of the best for both garden and market planting. August. 


\section{Plums.-Continued.}

Satsuma-Large; color purple and red with blue bloom; flesh firm, juicy, dark red or blood color, fiue quality; pit very small. Hardy and vigorous grower. August.

Wickson-This magnificent plum was produced by Luther Burbank, the "Wizard of Horticulture," as the result of a cross between Kelsey and Burbank.

Mr. Burbank says: "Among the many thousand Japan plums which I have fruited this one so far stands pre-eminent in its rare combination of good qualities.

"The tree grows in vase form, sturdy and upright, $y$ et as gracefully branching as could be desired, and is productive almost to a fault. The fruit is even1y distributed all over the tree, and from the time it is half grown until a few days before ripening it is of a pearly white color, but all at once soft pink shadings creep over it. and in a few days it has changed to a glowing carmine with a heary, white bloom. The stone is small; the flesh is of fine texture, firm, sugary, and delicious, and will keep two weeks or more after ripening, or can be picked when hard, and wi1l color and ripen almost as we11 as on the tree.

"A year ago I was convinced that this was perhaps the best of all Japan plums, and have yet no reason to change that opinion; I more than ever admire the clean, sturdy, vigorous, upright growth of the trees, the pleasing light gray bark, the habit of ripening its wood hard to the very tip, its productiveness, and the rare beauty and keeping qualities of its fruit of which both the size and quality have much improved since removing from the original hedge-row."

Season before 1ast Wickson plums sold at auction, wholes ıle, in New York City, for as much as $\$ 8.55$ per 20-pound box: more than 10 cents a plum. August and September.

Red June-The earliest large-fruited market plum. Red, with yellow, solid flesh; good bearer and keeper; a late blooning variety; one of the best. June.

\section{European and American Varieties.}

Simpson-A beautiful fragrant golden colored p1um, solid meat and perfectly free stone, spoken of in the highest terms by the state experiment stations. A cross between the American and European varieties. very hardy and profuse bearer. Only a limited number of trees left for shipment this spring.

Elwood-A large purple plum, similar to Lombard, but larger and better quality; very hardy. One of our customers in Iowa writes: "Ther have done so well here that I can sel1 a large quantity; the best plum erer grown here." An enormous bearer, very valuable. On1r a limited number of trees for this season.

Lombard-Medium, violet red, juicy, pleasant, good. hardy and productire, the leading market rariety. August.

Shipper's Pride-Large, dark purple. very showy, often measuring two inches in diameter, fine, juicr and sweet. September.

Wild Goose-Large, rict, crimson, beautifu1; flesh soft, rich, melting, delicious, with a full fruity flaror; tree a strong grower, prolific. This variety is amoug plums what the Ben Davis is among apples-referring to the American class of plums. July.

Wolf-Fruit near1y as large as Lombard, and a perfect free stone; qualicy superb for cooking and for serving with sugar; tree a good grower, hardy, and is becoming very popular wherever known, promising to lead a1l other 11ative plums. August.

other Varieties-German Prune. Imperial Gage, Washington, Bradshaw, Damson, Yel1nw Egg, Coe's Golden Drop, DeSoto. For est Garden, Wearer, Marianna, Pottawottomie. Forest Rose, Miner, Richland, Ogon, etc.

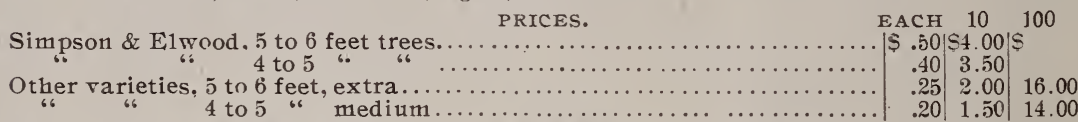

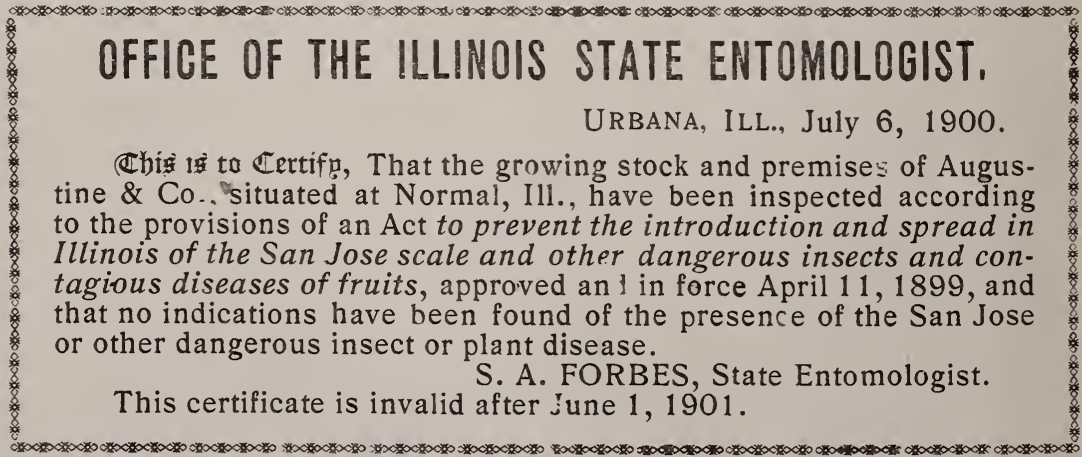

\section{Peaches.}

Varietie:-Alexander. Amsden. Ark. Traveler, Chinese Cling, CRAWFORD'S EARLY, Crawford's Late, Foster, Heatl iling, Wonderfui, Wheatland, Salway, Globe, Gen. Gar land', Forest Rose. Ward's Late, Conkling, Lemin Cling, Hill's Chili, Ear1y York, O1d Mixon Cling, O1d Mixon Free. Hale's Early, Elberta, Champion, Beer's Smock, Mt. Rose, Sneed (earliest), Triumph new), Foster. 


\section{Peaches.-Contrnued.}

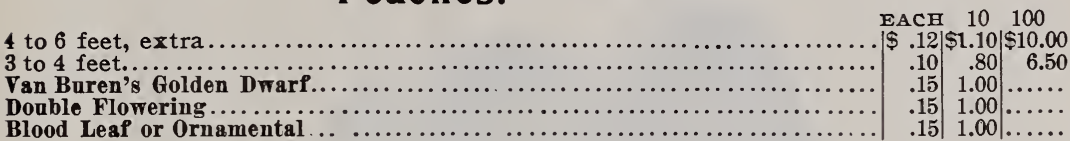

Apricots.

Varieties-Alexis, Alexander, Catherise, Gibes, Budd, Early, Golden, Moore Park, and Buda.

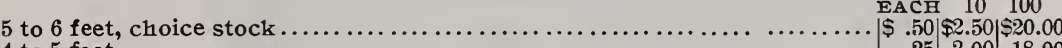

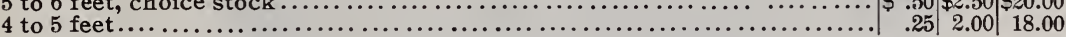

\section{Blackberries.}

Snyder-The best all-around Blackberry for Northern and Central EACH $10, \begin{array}{lll}100 & 1000\end{array}$

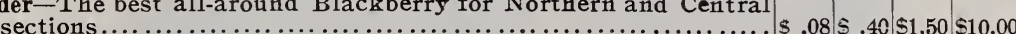

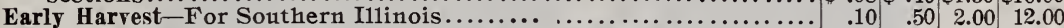
Stone's Hardy-Becoming popular; ripens two weeks after Snyder.. Dewberry-Lucretia........................................ $\quad .08 \quad .50 \quad 2.50 \ldots \ldots$. Erie-Large and delicious but not a heavy bearer................ $\quad .10 \quad .60 \quad 3.00 \ldots \ldots$.

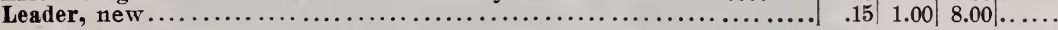

Leader Blackberry is a very promising new berry; almost an ever-bearer; fruit large and fine; few seeds; ripening heavy; crops as late as September. When all others are gone has sold for big prices, but most valuable for a fancy family berry.
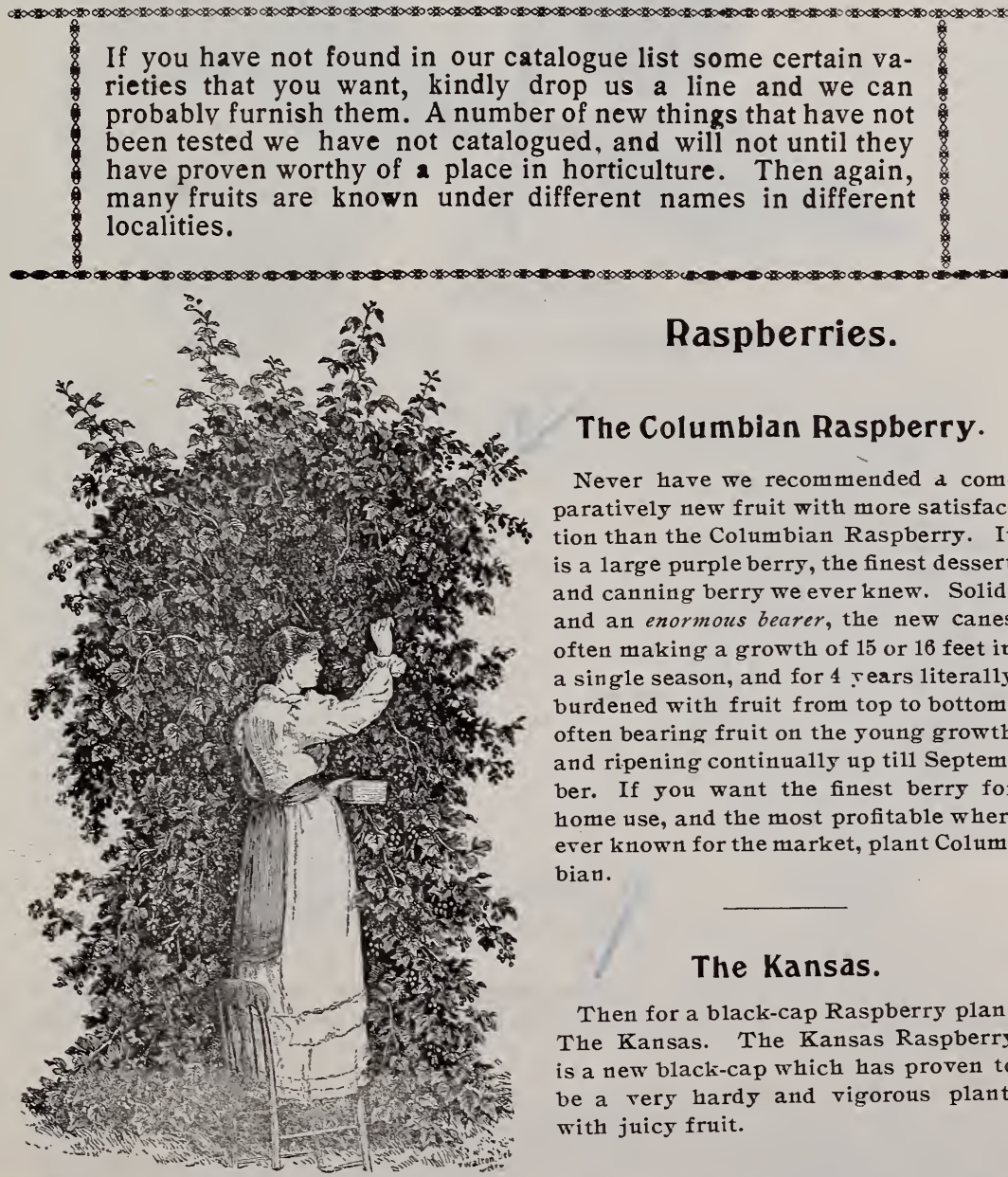

Raspberries.

\section{The Columbian Raspberry.}

Never have we recommended a comparatively new fruit with more satisfaction than the Columbian Raspberry. It is a large purple berry, the finest dessert and canning berry we ever knew. Solid, and an enormous bearer, the new canes often making a growth of 15 or 16 feet in a single season, and for 4 rears litera11y burdened with fruit from top to bottom, often bearing fruit on the young growth and ripening continually up till September. If you want the finest berry for home use, and the most profitable wherever known for the market, plant Columbian.

\section{The Kansas.}

Then for a black-cap Raspberry plant The Kansas. The Kansas Raspberry is a new black-cap which has proven to be a very hardy and vigorous plant, with juicy fruit. 


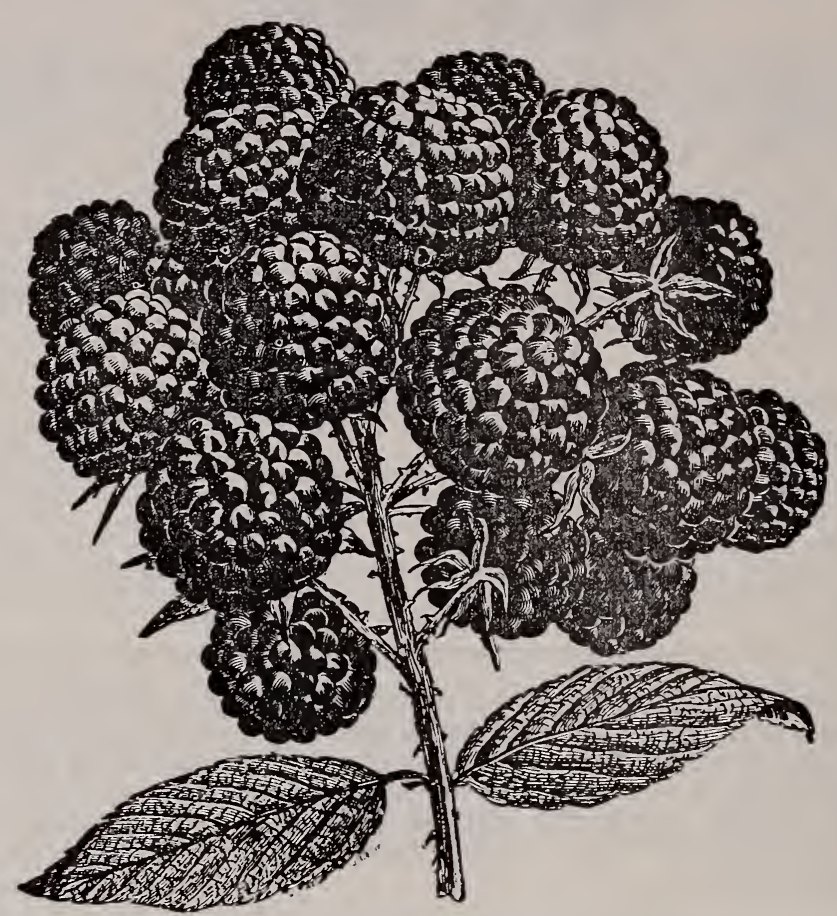

The Kansas.

\section{NEW RASPBERRY (not named) No. 64.}

No. 64 is a new seedling black raspberry not yet named by us. This berry is a very vigorous grower and a very abundant, annual bearer. Fruit, glossy black; comparatively few seeds; very nice and juicy: especially valuable for home use. We have fruited it for the past five years and feel safe in recommending it as the best among the many varieties we have tested. We have only a limited stock of plants to offer this year.

ЕАСН $\quad 10 \quad 160 \quad 1000$

New Raspberry, No. 64................................ .20 \$1.2.\$10.00|\$85.00

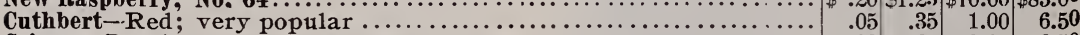

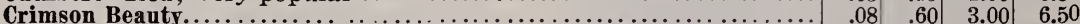

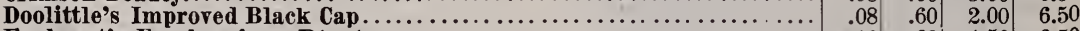

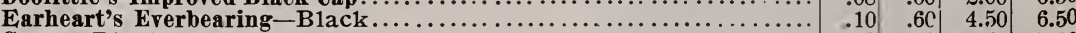

Gregg-Black; no better.................................... . .08 $\quad .40 \quad 1.50 \quad 7.00$

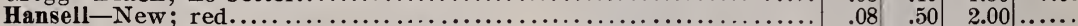

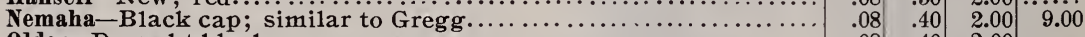

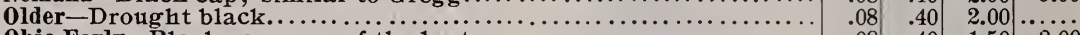

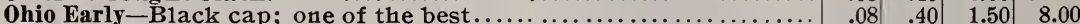

Shaffer's Colossal-Purple........................................

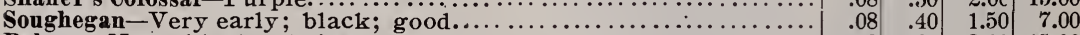

Palmer-New; black; choice................................. $.08 \quad .60 \quad 3.00 \quad 15.00$

Kansas.................................................. $\quad .08 \quad .40 \quad 3.00 \quad 12.00$

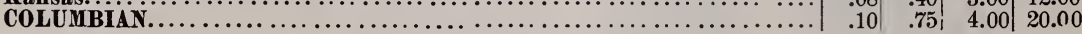

\section{Strawberries.}

Our Strawberries are not dug from old fruit beds, but from beds set especially for plants.

SENATOR DUNLAP.-A new berry; has been well tested. Originated by Rev. J. R. Reasoner, Seymore, I11. The following testimonials tell what it is:

Mr. F. R. Reasoner, Seymore, Illinois:

UrbaNa, Ill., Ju1y 22, 1899.

My DEAR SIR:-I have carefu1ly studied your No. 1 (Senator Dunlap) strawberry during the past three seasons, and have compared it with eighty-two other varieties grown on the station grounds, and do not hesitate to say, that it has greater merit than any other berry with which I am familiar. The plants are exceedingly vigorous, with clean 
healthy foliage, which has no tendency to rust. The berries are very large, roundish conical, regular, with a slight neck. In color they are glossy crimson, with the meat firm and solid, deep crimson throughout, and good in quality. It is a wonderfully productive strawberry. A1together, it is the most attractive strawberry I know of, and I predict a promising future for it. Yours very truly,

J. C. BLAIR, Asst. Professor of Horticulture.

"To me the most important result of my observations this season is the conviction that the Senator Dunlap is now the greatest all-round variety ever introduced. What I had seen and heard heretofore led me to this belief, and now it is confirmed. I believe the Senator Dunlap will take its place, not with the Haverland, Bubach and Clyde, for it is in a class above them, but at the top of the class that contains the Wm. Belt, Sample and Nick Ohmer. In size it is not the equal of any of these, but, aside from size, it has more to recommend it than any other variety now on the market with which I am acquainted. It is of the Warfield type, has a perfect blossom, is hardy, productive, a splendid keeper, and able to hold its own under any "rough-and-tumble" methods of culture to which it is 1ikely to be subjected."-From Cravjford's $\mathcal{F} u l y$, rgoo, Report on Strawberries.

The Senior member of our firm has been on the experimental grounds of the introducer and unhesitatingly endorses the above statements.

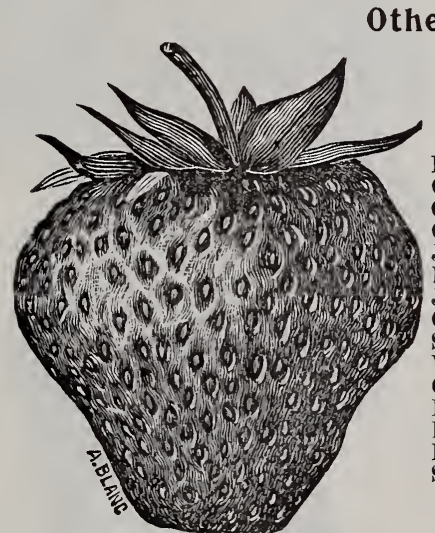

other Varieties are:

Warfield No. 2 .

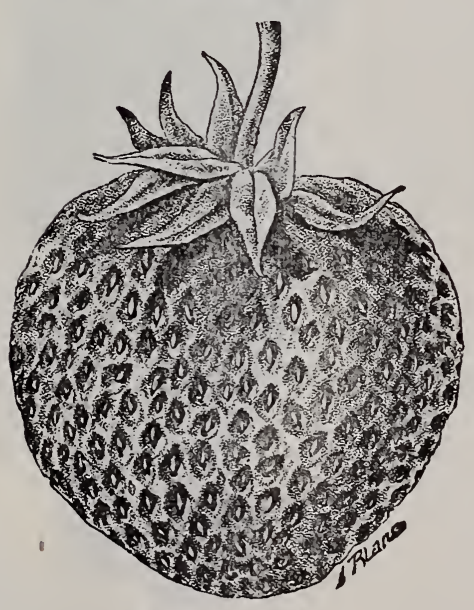

Bubach No. 5 .

Gooseberries.
$100 \quad 1000$

Bubach No. ó-Large, fine............. $\$$.75|\$ 4.00

Captain Jack-Large, early, productive.. $\quad 75$

Crescent .............................. $\quad .75$

Chas. Downing. ...................... .75 4.00

Jersey Queen ....................... $\quad .75$

Michel's Early-Good on poor 1and....... $\quad .75 \quad 3.50$

Jessie................................ $1.00 \quad 4.00$

Gandy-Late, one of the best............. $1.00 \quad 4.00$

Sharpless.......................... $1.00 \quad 4.00$

Warfield No. 2....................... $\quad .75 \quad 4.00$

Greenville-New, promises very good.... $1.50 \quad 7.00$

Parker Earle-New, one of the best...... 2.50 10.00

Bella-New and promising............ $2.00 \quad 10.00$

Bissell-New and good..................... $1.75 \quad 10.00$

Senator Dunlap-Fine plants............ $4.00 \mid 25.00$

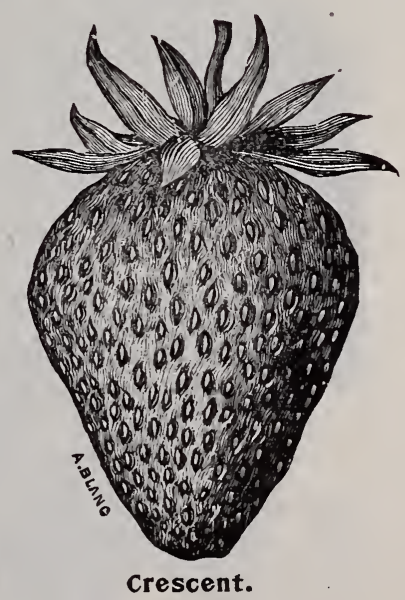

crescent.

EACH $10 \quad 100$

Downing-Probab1y the best native sort; berries large, round; an $\left.\left.\right|^{\$} .1\right|^{\$} .75||_{5.00}^{\$}$

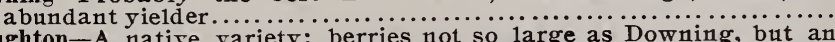

Houghton-A native variety; berries not so large as Downing, but an enormous bearer; succeeds everywhere; 2 years ..................... Industry-An English variety that stands in high favor; berries very large; heavy bearer, but mildews in some sections; 2 years.........

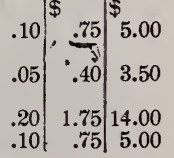




\section{Currants.}

Cherry-The largest of all the red Currants; berries sometimes measuring half an inch in diameter, bunches short; plant very vigorous and productive when grown on good soils and we11 cultivated.

Fay's Prolific-Color deep red; a great bearer; stems 1onger than Cherry and berries hold their size to the end of the stem better; quality first-class, not quite so acid as the Cherry; claimed to be the most prolific and best of a11 red Currants.

Red Dutch-The standard old variety; excellent and we11 known; a great bearer and a very profitable market sort.

White Grape-Very 1arge; yellowish white; sweet or very mild acid; excellent quality and valuable for the table; the finest of the white sorts; very distinct from White Dutch, having a low spreading habit and dark green foliage; very productive.

EACH $10 \quad 100$

Black Naples-2 years.......... $\$ .101 \$ .901 \$ 6.50$

Cherry -2 years ..................

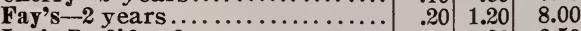

Lee's Prolific -2 years.............

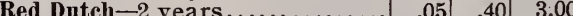

\begin{tabular}{ll|l|l|l|} 
Victoria-2 years................ & .08 & .60 & 4.50
\end{tabular}

Versailles-2 years..............

\begin{tabular}{ll|r|r} 
White Dutch-2 vears ........... & .05 & .40 & 3.00
\end{tabular}

White Grape-2 years..........

\begin{tabular}{l|r|r|r} 
North Star-Red; 2 years......... & .15 & 1.00 & 7.00
\end{tabular}

Crandall -2 years...............
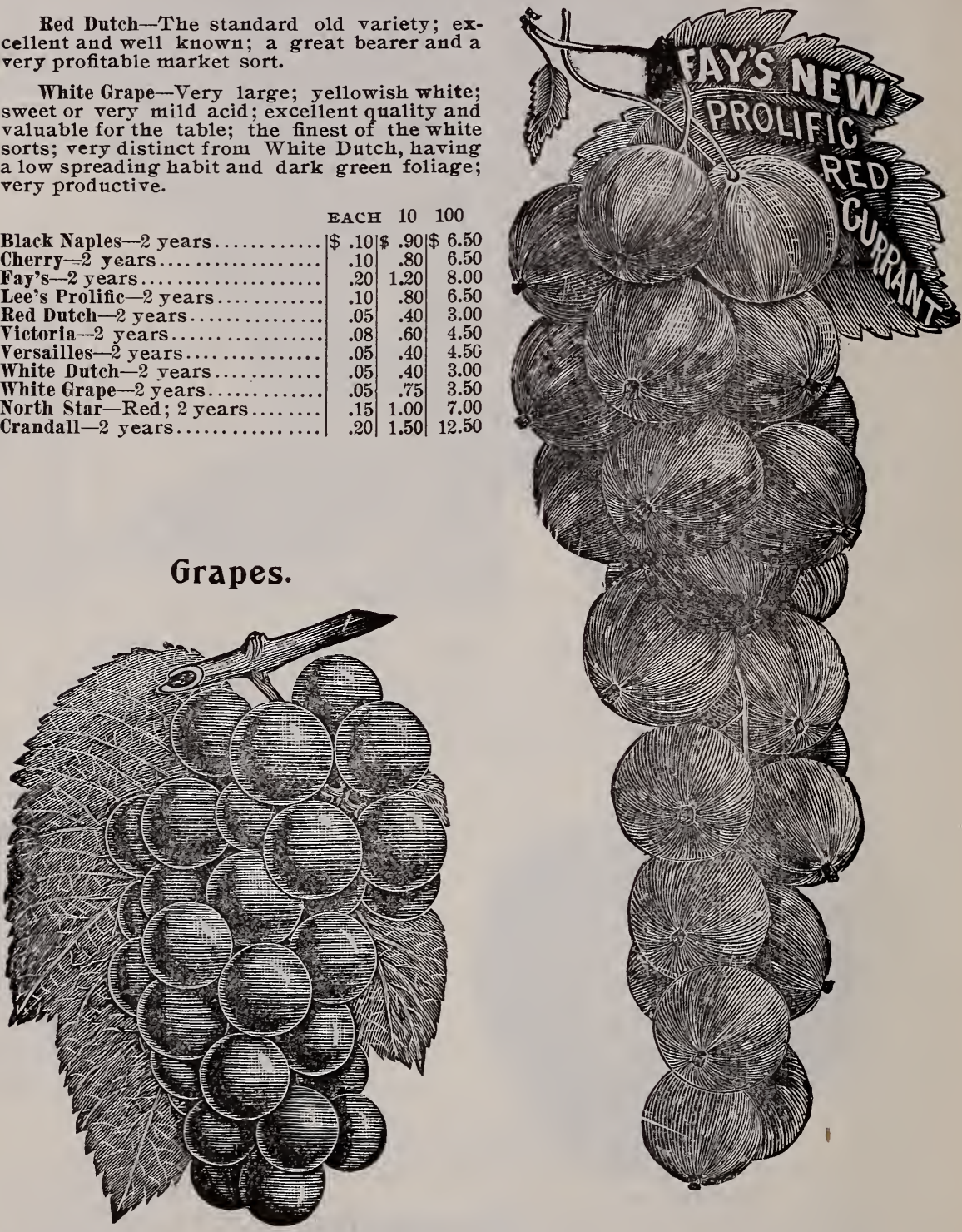

Moore's Early.

Grapes are one of the finest fruits grown for family use, ripening as they do over a period of two months or more. They are so healthful, so easily grown and the plants are so cheap, we would like to write a sermon on them, if we had room.

For general planting we prefer the Concord, Moore's Early, and Worden for blacks, the Pocklington, Niagara and Moore's Diamond for white, and Woodruff Red and Brighton for red $\mathrm{grapes.}$ 


\section{Black Grapes.}

Concord-Bunches large, berries large, round; skin thick and covered $\$$ with bloom; flesh, juicy, sweet. Vine very hardy, vigorous, productive; at present the most popular of all our native varieties; 2 years..

Clinton-Bunches medium size, com pact, shouldered; berries small; flesh acid vinous flavor. Vines hardy, vigorous, productive, but improves

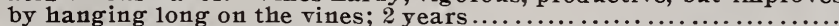

Champion-Bunches large and compact; berries large, covered with a rich bloom; medium in quality; vine a strong and healthy grower and a good bearer; profitable for market on account of its earliness; poor

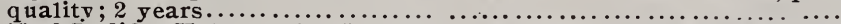

Hartford Prolific-Valuable in Northern localities. Bunches large, compact, shouldered; berry large, round; skin thick; flesh sweet, juicy; vine vigorous and exceedingly productive. Ripens two weeks before the Concord..............

Hoore's Early $-A$ large black grape of the Concord ty pe, the entire crop ripening before the Concord; bunch medium; berries large with blue bloom; flesh pulpy, of medium quality. Vine hardy, productire, better as it attains age. Planted extensively as a market sort. This is the finest black grape for general purposes grown, excepting possibly the

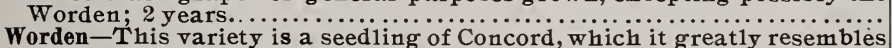
in appearance and flavor, but the berries are larger, the fruit is better flavored, and ripens severa 1 days earlier; 2 years.....................

\section{White and Red.}

Brighton-A cross between the Concord and Diana Hamburg; bunches large, berries of medium size; flesh sweet, tender and of the highest

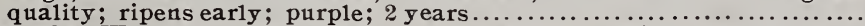

Catawba-Well known as the great wine grape of Ohio, Kentucky, etc.; bunches large and loose; berries large, of a copper color, becoming purple when wel1 ripened; 1ate, good, but 1 iable to rot; 2 years.........

Delaware-Still holds its ow $n$ as one of the finest grapes; bunches sma11, compact, shouldered; berries rather sma11, round; skin thin; flesh very juicy, without any hard pulp; an exceeding1y sweet, spicy and delicious flavor; vine moderately vigorous. If you have sandy soil be sure and plant a few Delawares. A delicious grape, but a little tender; 2 years

Empire State-(Rickett's)-A seedling from Hartford Prolific fertilized with the Clinton, hence very hardy and vigorous; bunches large, long, shouldered; berry medium to large; flesh tender, juicy and rich, with a slight native aroma; ripens very ear1y, and continues a long time in use; 2 years.............................................................. Golden Pocklington-Is a seedling from Concord; vine hardy, both in wood beautiful golden yellow; clear; juicy and sweet; very highly perfumed to the center, with little or no pulp; bunches very large, sometimes shouldered; berries round and very large and thickly set; quality, when fully ripe, much superior to Concord; ripens with the Concord; 2 years...

Martha-A seedling of the Concord, which it resembles in growth and hardiness; bunch of good size, and berry large, of pale green or light color; sweet, juicy, sprightly; ripens with Concords; 2 years............

Moore's Diamond-Very hardy, healthy and vigorous; ripens from 2 to 4 weeks earlier than Concord; a beautiful, clear white grape; large bunches, though berry is on1y medium size, but in quality not surpassed by anytbing we ever tested; as rich as nectar; and an abundant bearer. If you plant 10 vines you will wish you had a hund red; 2 years.........

Niagara-A magnificent white grape and very valuable for both garden and vineyard; a rank grower and very productive of beautiful bunches of the largest size; berries large, with a tough skin; quality good;

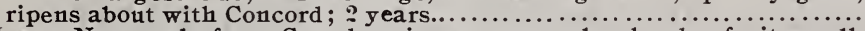

Moyer-New; red; from Canada; ripens very early; hardy, fruit small,

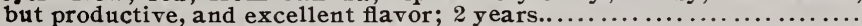

Woodruff Red-A fine looking, very large, red grape; has a pleasant flavor; exceedingly thrifty vine for a red grape, and very prolific. The best

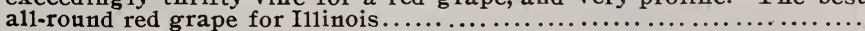

\section{Seedlings, Hedge Plants, Etc.}

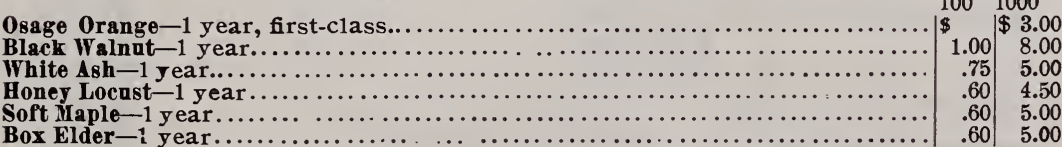

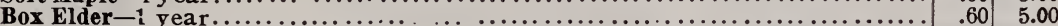

A11 orders for seedlings should be booked as ear1y as possible; we probably cannot fill orders for them after April 1.

\section{Miscellaneous.}

Lucretia Dewberry - Fruit very large, 1uscious and hand some; perfect1y hardy, a strong grower and enormous1y productive; a superb and very profitable market fruit; the vines should be allowed to remain on the ground during the winter, and staked up early in the spring. 


\section{Miscellaneous.--Continued.}

\begin{tabular}{|c|c|c|c|}
\hline \multirow{2}{*}{ 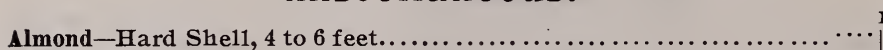 } & EACH & 10 & 100 \\
\hline & & $\$ 1.75 \mid \$$ & 16.00 \\
\hline 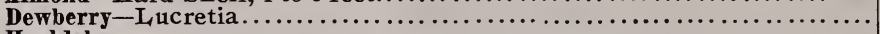 & .05 & .30 & 50 \\
\hline 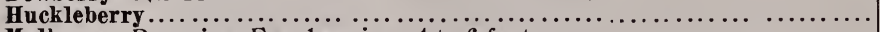 & .15 & & 9.00 \\
\hline 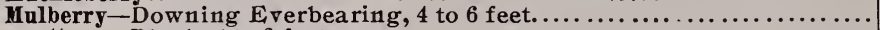 & .35 & & \\
\hline & .25 & & \\
\hline$\ldots \ldots \ldots \ldots \ldots \ldots \ldots$ & .10 & .7 & \\
\hline 66 & & & \\
\hline & .15 & 1.2 & \\
\hline & .35 & 3.0 & \\
\hline & & & \\
\hline 66 & .25 & & \\
\hline $\mathrm{ce}-\mathrm{Or}$ & .20 & 1.7 & \\
\hline $\mathrm{Ch}$ & .20 & 1.7 & \\
\hline 66 & .25 & 2.00 & \\
\hline
\end{tabular}

\section{Garden Roots.}

Asparagus -2 and 3 years 1001000

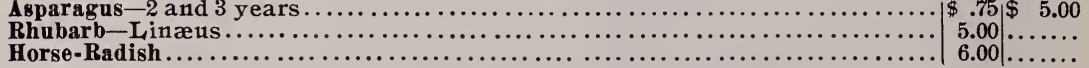

\section{Evergreens-Transplanted and Root Pruned.}

We want to ca11 your special attention to these evergreens. They have a11 been several times transplanted and root pruned to make plenty of fibrous roots, so that the risk replanting them is but 1ittle. On1y be sure that the roots are not exposed at a11. If evergreen roots once get dry they are gone, for the sap turns hard and the trees will never recover.

If you want a wind-brake plant Norway Spruce or Arbor Vitæ. Especially the A rbor Vitæ; cheaper now than they will likely be again for some time.

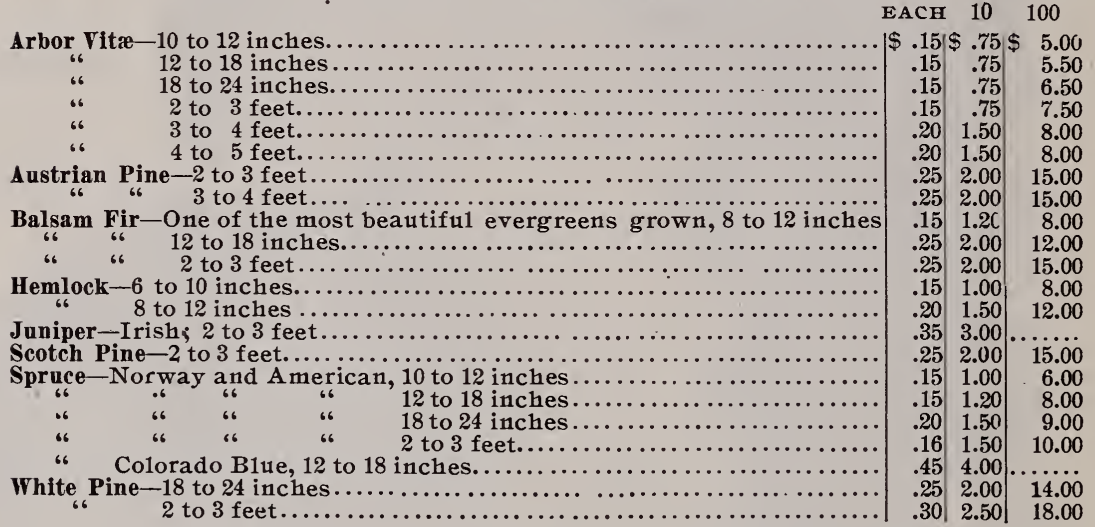

\section{Deciduous Ornamental Trees-Transplanted.}

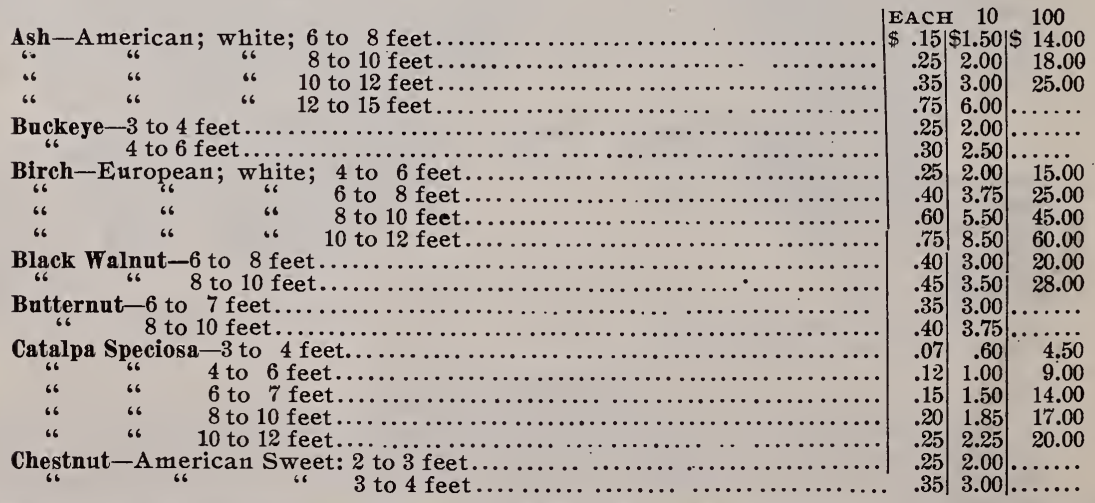




\section{Deciduous Ornamental Trees-Transplanted-Con.}

Elm-European white. The European white is one of the finest shade EACH 10100 and ornamental trees grown, long lived, hardy, as rapid a grower as the soft maple, making a tree that, in our estimation, is not equaled by any of our native trees.

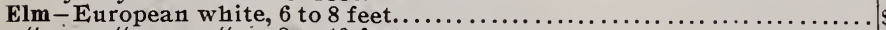

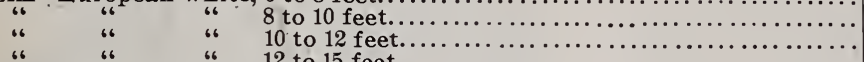

12 to 15 feet

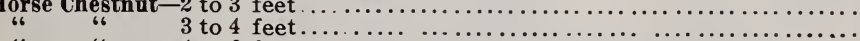

" 6 6 4 to 6 feet.

Judas Tree-Red Bud, 5 to 6 feet..

Larch-American; 6 to 8 feet.

Maple-Box Elder; 6 to 8 feet.

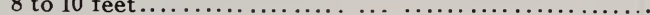

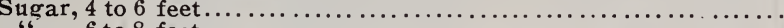

Norway, 4 to 6 feet.....

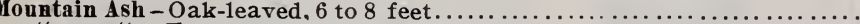

European, 5 to 6 feet.

"6 " 6 "6 6 to 8 feet.

Peach-Van Buren's Golden Dwarf

Double Flowering .

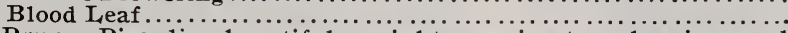

Plum-Prunus Pisardi; a beautif $u$, upright, growing tree, bearing good fruit, especially for cooking. Leaves are blood red in color; tree is

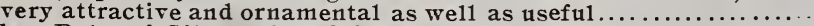

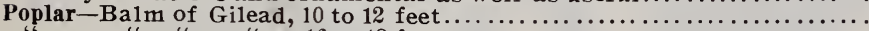

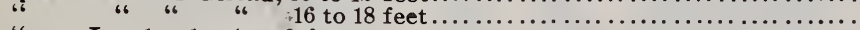

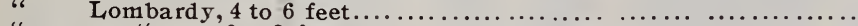

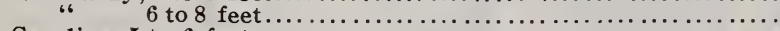
Carolina, 5 to 6 feet...

6 to 8 feet.

66 8 to 10 feet.

Tulip-(Yellow Poplar) 12 to 14 feet.

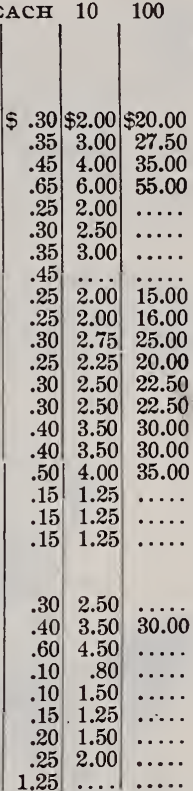

\section{PROTECT YOUR TREES}

FROM......

RABBITS, BORERS AND SUN SCALD

$\mathbf{U}$ NDOUBTEDLY the best and cheapest device for protecting fruit trees from rabblts, mice, borers and sun scald, is what is known as the VENEER PROTECTOR. This consists of a thin, pliable piece of wood, $7 \frac{1}{2} \times 22$ inches, which is wrapped around the tree and fastened at the top and bottom by a light wire. They will Iast several years and are the cheapest and most easily applied protection we know of, and in using this protector you do not learn the lesson of ruining your trees by any of the so-called protection washes and paints, which.have ruined trees and orchards without number.

....We have used about 40,000 of these protectors in our own.orchards; have had them in use for five years, and after testing them for this length of time, we are convinced they are the best thing on the market.

100 $\$ 1.50$

500 at thousand rates.

$1000 \ldots \ldots \ldots \$ 7.50$

5,000 or over...............\$6.00 per 1,000

Delivered f.o.b. Normal, 111.

Cash withlorder and no discount.

\section{Bulbous Plants.}

\section{DAHLIAS.}

This is a flower that everybody can have in abundance. The bulbs are as easily grown as potatoes. If you buy a dozen this year you should have nearly a hundred next year. It remains in blossom a long time; it is exceedingly showy and beautiful. Our assortment is the most beautiful we have ever seen, embracing the best colors. We will guarantee them to gratify the most fastidious. Our bulbs are all named varieties, and will be truly labeled, but we reserve the right of selection, as we are not overstocked. State colors desired. 


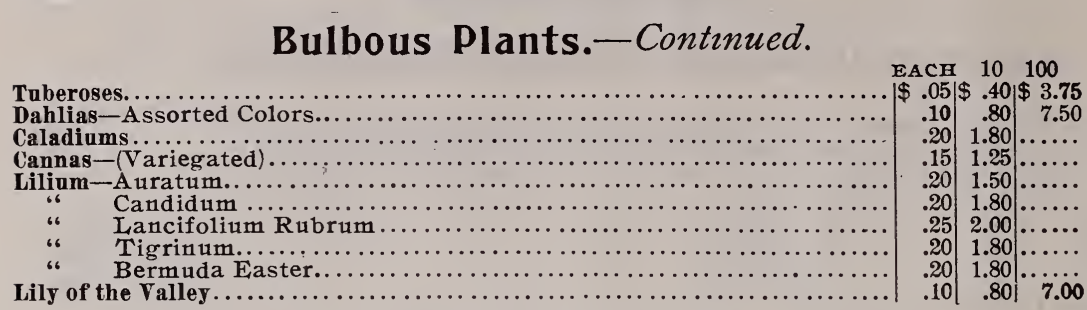

\section{Ornamental Shrubs.}

Japan Quince (Pyrus $\approx$ aponica)-We assure you that there is nothing in the way of flowering out-door plants that will please you more than this plant. We prefer to grow it in tree form, cutting back the last season's growth severely each spring and by this method securing a larger flower and better shaped bush than if left to its own way of growing.

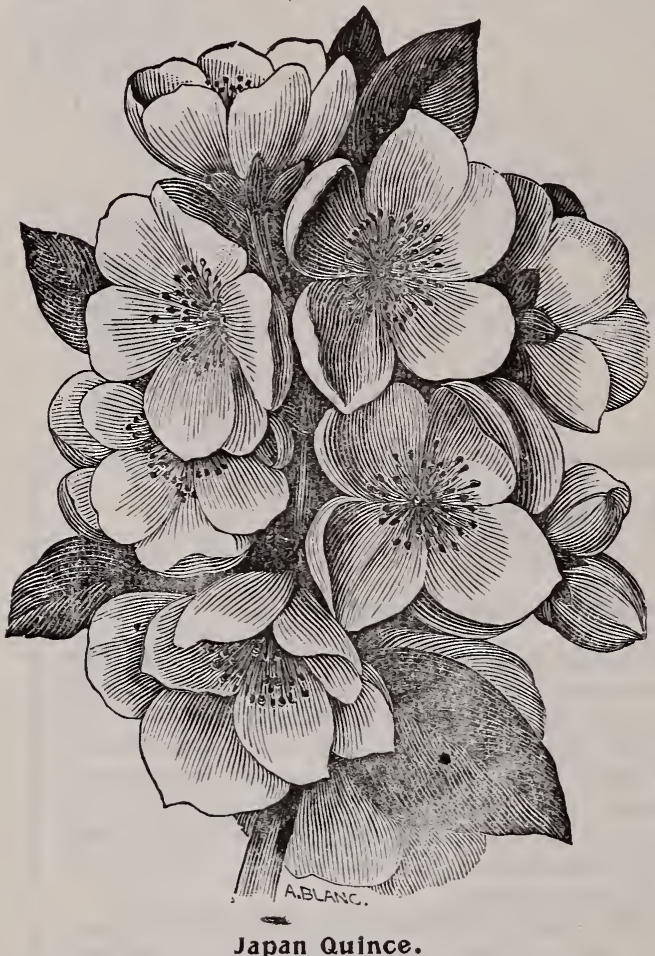

\begin{tabular}{|c|c|c|}
\hline & & 10 \\
\hline and pink............. & .25 & 2.0 \\
\hline Althea-(Rose of Sharon) & .25 & 2.0 \\
\hline rberry-Furpie leav- & & \\
\hline $\begin{array}{l}\text { ed, } z \text { to } 3 \text { teet......... } \\
\text { Berberry-Purple leav- }\end{array}$ & .25 & \\
\hline ed,red fruited,2 to $3 \mathrm{ft}$ & .30 & 2 \\
\hline erberry-Common, 18 & & \\
\hline$s \ldots \ldots \ldots$ & .25 & 2. \\
\hline iionanthus $-\mathrm{W}$ h i t e & .25 & \\
\hline fringe ... & .15 & 1 \\
\hline Chionanthus -2 years... & .35 & \\
\hline $\begin{array}{l}\text { Deutzia-Fortunii, white } \\
\text { flower; dwarf; hardy; }\end{array}$ & & \\
\hline Scabra, Crena & & \\
\hline $\begin{array}{l}\text { Wellsi .................... } \\
\text { Euonymus-Am. Straw- }\end{array}$ & .18 & \\
\hline berry Tree, 6 to 8 feet & .2 & 2.0 \\
\hline Euonymus-Am. Straw- & & \\
\hline $\begin{array}{l}\text { berry Tree, } 8 \text { to } 10 \mathrm{ft} \text {. } \\
\text { Gordon's Fowering Cor. }\end{array}$ & .30 & \\
\hline 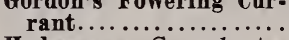 & .20 & 2.0 \\
\hline Hydrangea-C o r d a t a & & \\
\hline $\begin{array}{l}\text { white..................... } \\
\text { Hydrangea-Pan. }\end{array}$ & 20 & \\
\hline hard $y, 2$ to $3 \mathrm{ft} . . .$. & .25 & 2.00 \\
\hline Honeysuckle - Upright, & & \\
\hline $\begin{array}{l}\text { white, } 3 \text { to } 4 \text { feet... } \\
\text { Honeysuckle-Pink, } 3\end{array}$ & .20 & \\
\hline 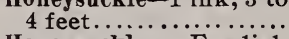 & .20 & \\
\hline Honeysuckle - English & & \\
\hline F1y, 3 to 5 feet......... & .20 & \\
\hline $\begin{array}{l}\text { Japan Quince-PyrusJa- }- \text { Py } \\
\text { ponica }-1 \text { to } 3 \text { feet.... }\end{array}$ & 25 & \\
\hline Lilac-White, 2 to 3 feet & .20 & \\
\hline "6 Purple,2 tc & .20 & 1.50 \\
\hline Persian, 3 to $4 \mathrm{ft}$. & .25 & 2.0 \\
\hline Joseka, 3 to 4 feet & .20 & \\
\hline "R Roto mangin- & & \\
\hline Privet-2 to $3 \mathrm{f}$ & . 20 & \\
\hline & .15 & \\
\hline & .15 & \\
\hline & & \\
\hline & .20 & \\
\hline runifolia, Th & & \\
\hline ergia, Opu & .20 & \\
\hline & & \\
\hline & & \\
\hline
\end{tabular}

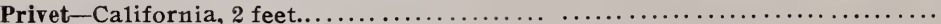

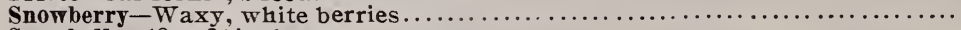

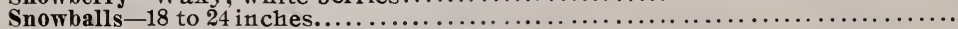

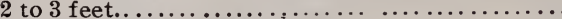

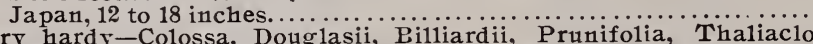
Spirea-Very hardy-Colossa, Douglasii, Rilliardii, Prunifolia, Thaliaclorides, Reevesii, Dundilian, Van Hout Zephri, Diantha, Flores and Gordona.

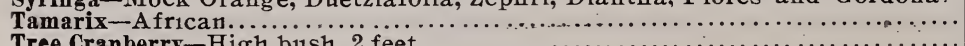

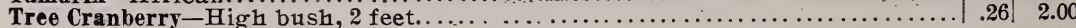

\section{Vines and Creepers.}

Ampelopsis-Quinquifolia (Virginia Creeper) Hardy................... $\$ .15|\$ 1.20| \$ 10.00$

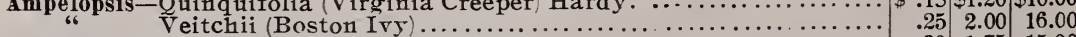
Bignonia Grandifiora, or Trum pet Creeper............................ $.20 \quad 1.75 \quad 15.00$ Honeysuckle-Yellow Trumpet, Scarlet Trumpet, Halleyanna, Chinese,

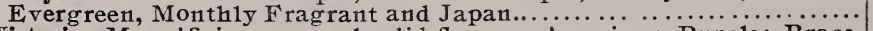
Wistaria-Magnificia, new, splendid flowers; American Purple; Brace-

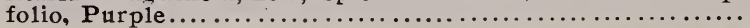
\begin{tabular}{l|l|l}
.15 & 1.20 & 10.00 \\
.20 & 1.50 & 14.00
\end{tabular} 


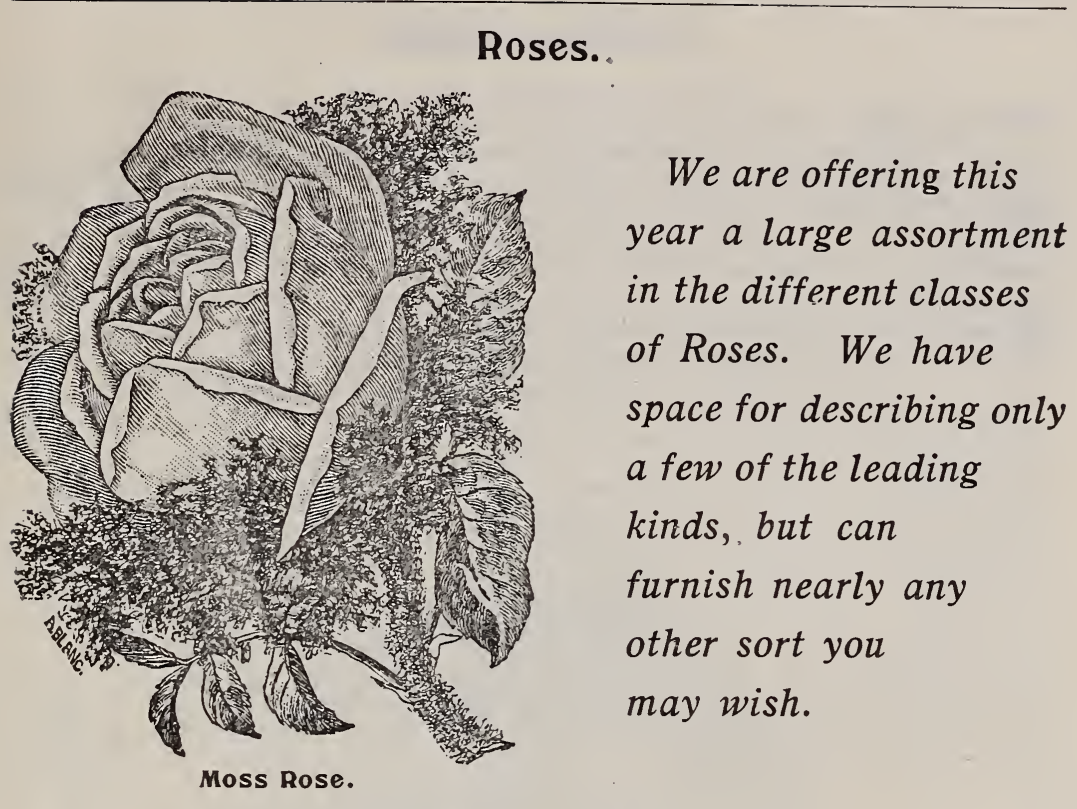

\section{Hybrid Perpetual.}

These roses are entirely hardy. They thrive best in a rich, well prepared loam. close pruning is generally required. Flower double and usually fragrant. They flower freely in June and at short intervals during the summer and autumn months.

General Jacqueminot-Probably the most prominent of the Hybrid Per-EACH 510 petual class; brilliant crimson; large and showy; a very fine grower.. $\$ .20 \$ . \varepsilon 5 \$ 1.50$ Anna De Diesbach-A bright, large rose of brilliant rose color; slightly

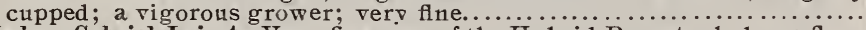

Madam Gabriel Luizet-Very fine rose of the Hybrid Perpetual class; flower fine and satiny pink...................

Magna Charta-One of the most popular sorts: color a bright pink suf-

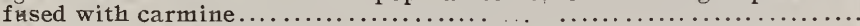

Paul Neyron-A deep rose color; satiny pink in the center; probabis the largest Hybrid; foliage very beautiful; very double; fragrant; a free bloomer; very desirable as a garden rose....

Iarshall P. Wilder-Said to be the very finest $\mathrm{H}_{5}$ brid Perpetual Rose; blooms usually long after other varieties are out of flower; color a bril liant red...

Marchioness of Lorne $-\mathrm{A}$ very fine free-blooming variety. Fiowers of a rich rose color, peculiarly cup-shaped, slightly shaded in center with

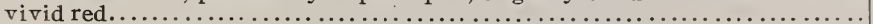

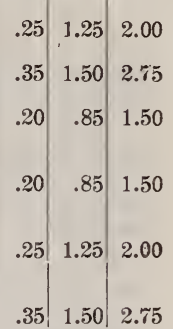

\section{Summer Roses on Own Roots.}

Madam Plantier-A rery abundant bloomer; clusters; very hardy; double;

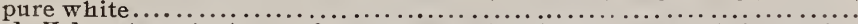

Lady Helen tewart-A very free grower; abundant bloomer; bright crim-

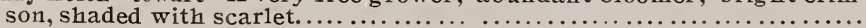

$$
\begin{array}{|r|r|c}
\text { EACH } & \multicolumn{1}{|c|}{5} & 10 \\
.15 & .60 & 1.00 \\
.20 & .85 & 1.50
\end{array}
$$

\section{Moss Roses.}

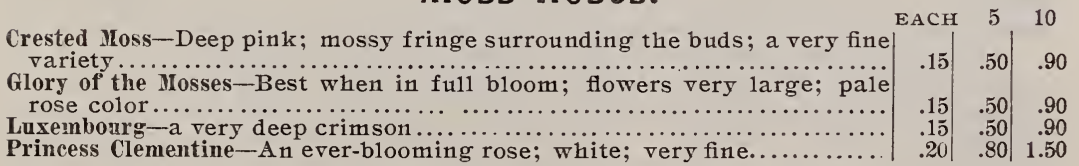

\section{Perpetual Moss Roses.}

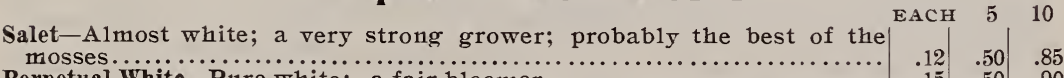

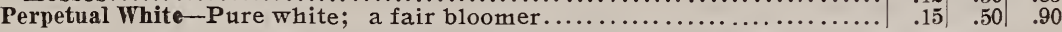




\section{Climbing Roses.}

Empress of China-A fine climbing rose which has been thoroughir tested in this locality. It readily withstands our winters. Blooms in clusters. Flower of good size, bright pink, very attractive. Truly an

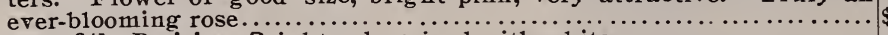

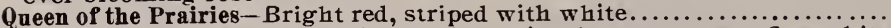

Baltimore Belle-Pearl color, flowers borne in clusters; a very fine white

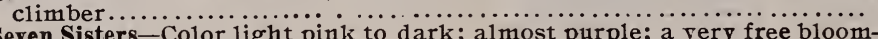

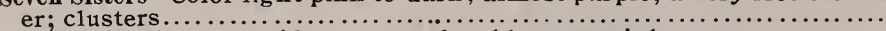

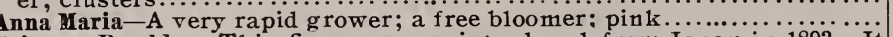

Crimson Rambler-This fine rose was introduced from Japan in 1893. It is a very vigorous grower, makiny shoots from six to ten feet in a season. It is equally valuable as a pillar or bush rose. The flowers are borne in trusses which carry from 30 to 50 blooms. Individual flowers measure fron 1 to $1 \frac{1}{2}$ inches in diameter. Foliage bright green and

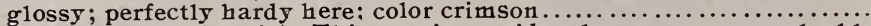

Yellow Rambler-Ag1aia) - This rose is considered an even more valuable introduction than the Crimson Rambler, for it is the hardiest yellow climbing rose yet introduced. The quality of hardiness has been an extremely difficult one to combine with yellow color. It has withstood prolonged low temperatures unprotected. With very slight attention it should grow everywhere that other roses succeed. It is a blood relation to the Crimson Rambler, which it much resembles in vigorous growth and foliage. It also blooms after the same manner as Crimson Rambler, in large trusses. The flowers are very sweetly fragrant, a quality not possessed by the furegoing variety. The "Aglaia," or "Yellow Rambler," was originated by Mr. Peter Lambert, one of the 1argest and most reliable rose growers of Europe. He has tested the rose for the past eight years, which, together with the reputation of the introducer,

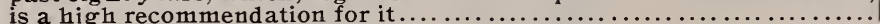

\section{Tree Roses.}

These are roses of any of the previous sorts, budded (usually) in sucli a manner as to make a dwarf tree; profuse bloomers; very ornamental and attractive.

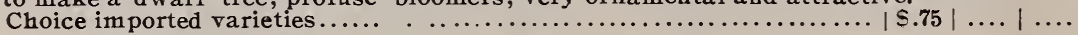

\section{Clematis.}

Can be sent by mail. Add ten cents (10c) each for postage.

Coccinea-Bright scarlet; profuse bloomer from June till frost..........

Duchess of Edinburg-Very fine, double white; frag rant $\ldots \ldots \ldots \ldots \ldots \ldots \ldots$
Flammula-Rapid grower; sweet scented; flowers smail white; borne in clusters.

General Grant-Very hardy; large flowers resembling the Henryii; reddish purple shaded with red; a distinct American variety ..............

Henryil-New; a fine Hybrid Perpetua1; flowers large and white...........

Jackmanii-One of the most popular and best known varieties; flowers from 4 to 6 inches in diameter; blooms continually from July until

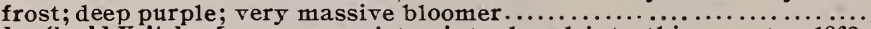

John Gould Veitch-Japauese variety; introduced into this country 1862; flowers very handsome; light blue or lavender........................

Jackmanii Alba-A11 the characteristics of the popular Jackmanii variety;
well tested; free blooming; flowers nearly pure white.................

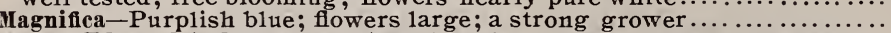

Madam Edouard Andre-A new French variety; a great novelty; the nearest approach to a large red clematis known; often called the Crimson Jackmanii. This clematis was exhibited at the World's Fair, Chicago, 1893, in the French department, and attracted great attention; a very strong grower, being a Hybrid of Jackmanii, which it resembles in

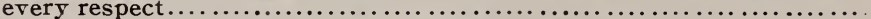

Madam Baron Veillard-Flowers very large; rose color shaded with light

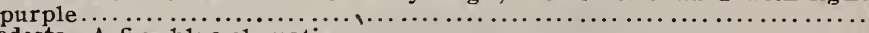

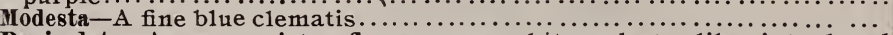

Paniculata-A new variety; flowers pure white and star like; introduced from Japan; a very rapid grower and is especially valuable for the covering of trellises and arbors; foliage a beautiful green. The whole plant appears as one mass of bloom, the foliage shining through only

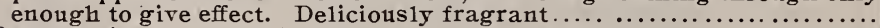

Kamona-A perpetual bloomer; a very strong grower; color a very fine

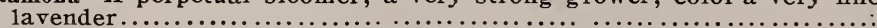

Star of India-A novel variety; violet to purple with a red bar in the cen-

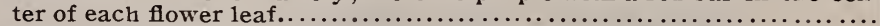

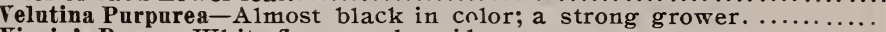

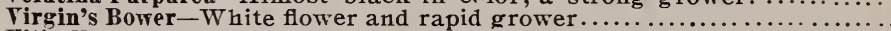

Viticella-A rery rapid grower; bears drooping flowers, usually purple.

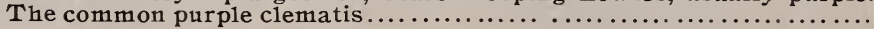

EACH $5 \quad 10$

$\$ .20|\$ .90| \$ 1.80$

$.40 \quad \cdots \cdots . . . . .$.

\begin{tabular}{ll|l}
.20 & .85 & 1.60
\end{tabular}

$.60 . . . . . .$.

$.40 \ldots \ldots . \cdots$

$.40 \quad 1.75 \quad 3.25$

$.50 \ldots \ldots \ldots$

.40

(10..............

$.40 \ldots \ldots$

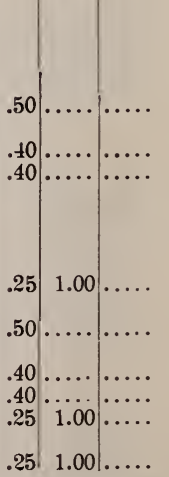




\section{Weeping Trees.}

\section{NAPOLEON WEEPING WILLOW.}

The most beautiful ornamental tree of its kind grown. The original stock came directly from the famous Weeping Willow trees growing around the grave of Napoleon on the Island of St. Helena. The origina1 stock came to us through Mr. A. T. Sherman formerly of this place. Some years ago a missionary returning from Africa, who was a great admirer of Napoleon Bonaparte, stopped to visit his grave off the southwest coast of Africa. He cut two small twigs from the Weeping Willow over Napoleon's grave and brought them back in a potato. For kindness done the missionary, Mr. Sherman was presented with one of these twigs, which was planted in Evanston, I11., nd has since grown to be a magnificent tree.

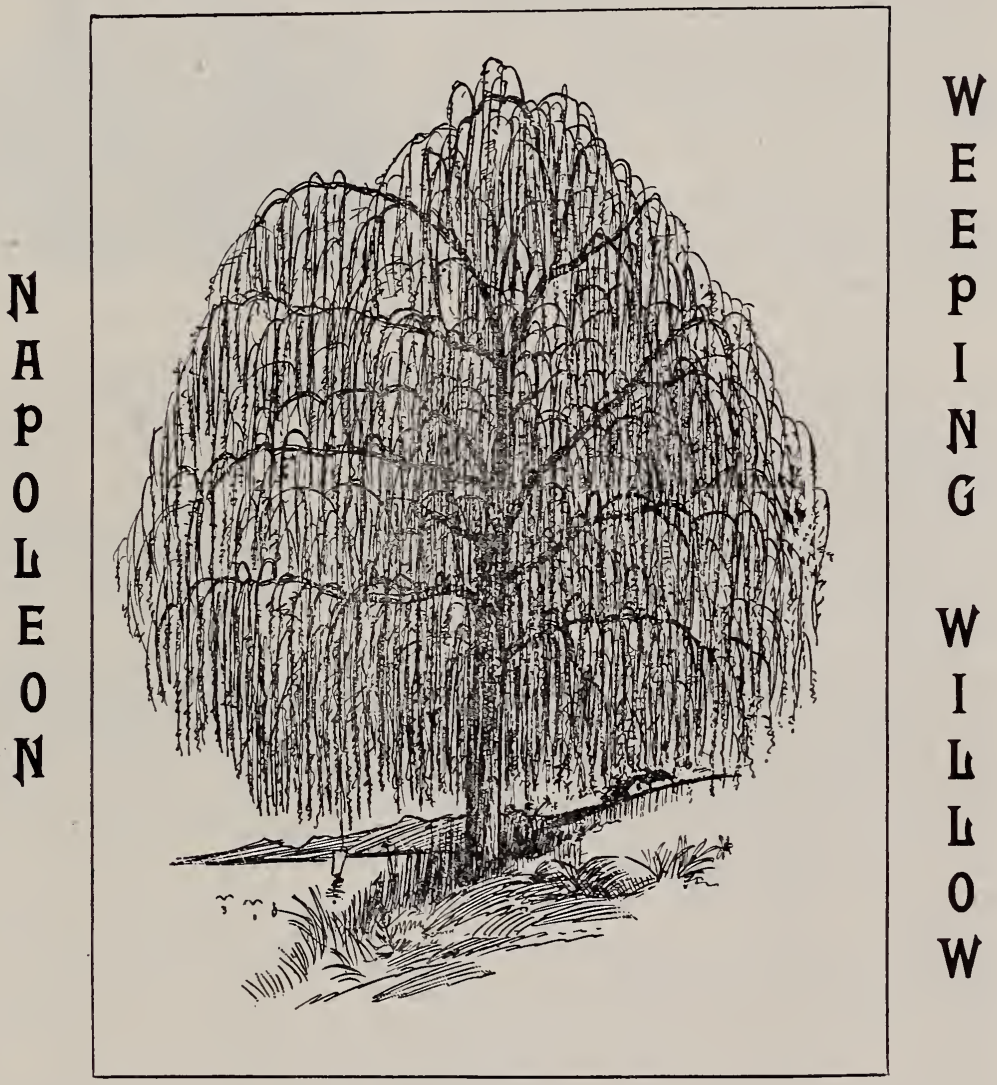

This tree, as well as the trees propagated from it, hare proven perfectly hardy in the most severe winters in the northern part of the state. The trees are rapid growers and in a few years' time are covered with fine weeping branches from top to bottom, often ten to fifteen feet in length and no larger around than a knitting needle.

For a weeping tree it has no equal, and when its historical charm is also considered there is nothing finer to plant for ornamental effect, and especially for cemeteries. We have only a limited number of trees.

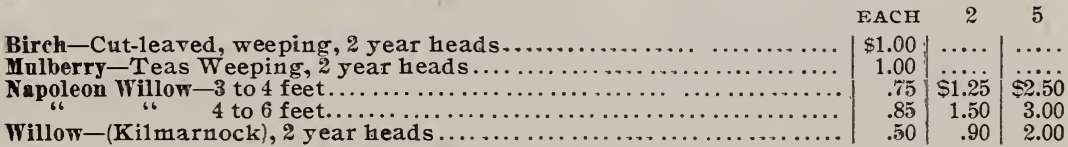




\section{Hardy Herbacious Plants.}

\section{Yucca Filamentosa.}

(An Ėvergreen.)

This plant is an object of beauty the year round, if its leaves alone are seen. These are one to two feet long, bristling out at all angles with sharp points, flower stalk stout, four to five feet high, with fifty to two hundred bell-shaped, creamy white blossoms hanging from branching arms. It is of a tropical appearance and truly magnificent. Perfectly hardy, and lives to a great age. This plant, used for borders, has for years been the ad ${ }^{-}$ miration of a11 beholders. Not on1y are they attractive while in bloom, but during the Fall and Winter their bright green foliage is a1ways a pleasing sight.

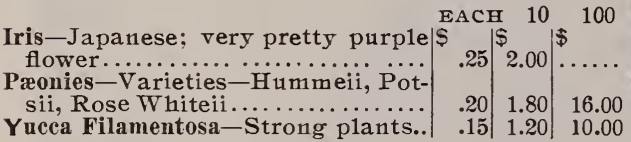

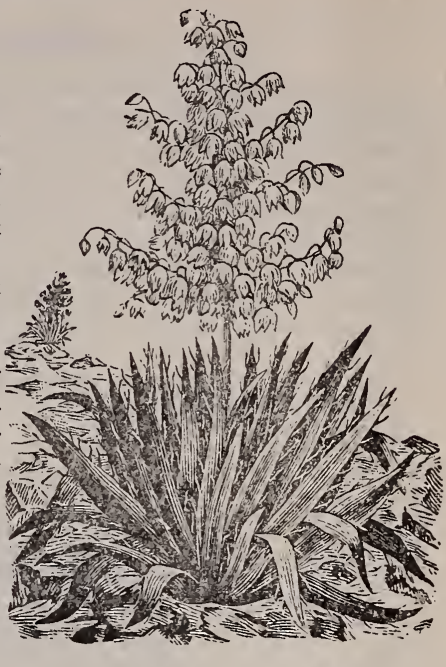

Yucca Filamentosa.

\section{Our Specialty-The Sudduth Pear.}

A TEST OF 80 YEARS.- The Sudduth Pear has stood a test of 80 years during which time it has never been known to blight or fail to bear a crop of fruit. The original tree has frequent1y borne as high as 80 bushels in a season and the 5 oung trees as high as 50 and 75 bushels.

ORIGIN. - In 1820 Thomas Constant came to I1linois from Xenia, Ohio, and entered a farm from the government near Sherman in Sangamon County. He brought with him a pear seed which he planted and from this sprang the original Sudduth Peartree. This tree came into bearing in 1826 and from then till now it has not failed to bear a single season. The original tree is growing upon what is now the Sudduth Estate some seven miles from Williamsville.

HARDINESS AND LONGEVITY. - The Sudduth is as hardy as an oak. It has been planted in nearly every state in the Union and Canada and we have yet to learn of a single branch or bud being injured either by severe winter weather or by the blight. The character of the growth is similar to that of a forest tree. The original tree is 80 years old, 55 feet in height, trunk over 10 feet in circumference. Trees grafted from the original tree are growing in Sangamon County from the age of 9 jears to 68 years. They have all the characteristics of the old, origina1 tree.

AY ORYAIEYTAL TREE AND RAPID GROWER. - The Sudduth Pear makes one of the most beautiful oruamental trees grown. They are perfect1y uniform, strong, thrifty upright growers, and have been pronounced by pos many equal or superior to the hard niaple as an ornamental and shade tree, being much more rapid in growth.

BLIGHT PR00F. - The Sudduth Pear is abso1ute1y free from blight or disease and is the only blight-proof pear known. The old trees in Sangamon County have been neglected and blighting trees have been allowed to remain around them, and yet no trace of blight has been discovered on them. We have in our own experimental grounds several Sudduth in very clese proximity to blighting trees. There are over 200,000 of these

The man that plants an acre of Sudduth pears is making a life investment that will in a fers years giz'e him an annual income better than the best 100 acre farm in the country. the nursery and not one of them has shown any indication of the blight. Experiments at inoculation have been tried and yet the most virulent form of blight inserted into the growing wood has not even made a black spot.

BEARS VERY YOUYG. - Trees only two years from the graft have matured a crop of fruit and they come into bearing very early. We present herewith cuts from Mr. Dillon's trees, which show the trees in bearing 2 years from the graft and also the trees as they appeared this last summer. This year we had joung trees bearing in the nursery row; a single tree three years old from the graft had over 500 blossoms apon it and matured as much fruit as it was able to carry.

FRUIT OF SCPERIOR QUALITY. - The fruit which ripens about the first to the fifteenth of October is of medium size. The color when thoroughly ripe is greenish yellow; skin stronger than common; com parative1y seedless and coreless; meat clear throug $\mathbf{b}$; no gritty substance so common in pears. The fruit has always brought the highest market price wherever known. The quality cannot be excelled for both dessert and canning fruit. Its exceptional freedom from worms and insects is very noticeable. 


\section{Our Specialty-The Sudduth Pear.-Continued.}

This fall we had a quantity at our office which was tested by a good proportion of the business men and fruit growers of Normal and vicinity and we append some of their testimonials.

Normal, Ill., December 20, 1900.

I have had the opportunity frequent1y in the past four years to eat the Sudduth Pear, and say unhesitating1y, that I regard it the richest and best flavored pear I have ever eaten.

DR. J. W. CRIGLER,

Prop. Normal Novelty Works.

NoRmal, Ill., December 20, 1900.

I have frequently had the pleasure of eating the Sudduth Pear, and in my judgment it is as finely a flavored fruit as I have ever tasted. So many pears have a woody and tough texture, but the Sudduth is very fine, and when ripe almost melts in your mouth. Very truly, C. S. NEELD, Postmaster.

To Whom It May Concern:-

Normal, Ill., December 2, 1900.

For the last two falls I bave had the privilege of eating some of the celebrated Sudduth Pears. Am frank to say that the flavor is very excellent, and it is the nicest pear that I have ever eaten.

J No. M. Elliot T, M.

NoRMal, Ill., December 20, 1900. eaten.

I have tested the Sudduth Pear, and regard it among the best pears $I$ have ever President I11inois State Norma1 University.

Normal, Ill., October 1, 1900.

Recent1y I had an opportunity to eat some of the Sudduth Pears, and am pleased to say tbat this pear is of medium size, rich and juicy, and of fine aromatic flavor, comparatively free from core and seeds, and in my judgment a very desirable dessert fruit. J. Y. THORP, Fruit Grower.

NoRMaL, ILl., December 21, 1900.

To Whom It May Concern:-

It has been my pleasure on more than one occasion to sample the Sudduth Pear. I cheerfu11y testify to its excellent qualities of flavor and richness.

E. A. Fritter, Superintendent City Schools.

\section{Augustine \& Co., Normal, Illinois.}

DEAR SIRS:-I am great1y obliged to you for having called my attention last fall to that remarkable seedling pear tree found growing in your state near Spring field.

As director of the Experiment Stations established by the Iowa State Horticultura1 Society, I have been constantly on the lookout for old and new fruits that seemed promising for trial at our stations, and especia11y for a pear tree that is perfectly adapted to our prairie soil and climate. Having just returned from a special visit to that wonderful seedling peartree, now named and known as "The Sudduth Pear," and from the evidence of the tree and from information concerning it there obtained, I believe the great desideratum has at last been found. After seeing the original tree aud interviewing Mr. Sudduth, on whose land the tree is growing, and other persons in the vicinity, I found that the statements concerning it as to origin, age, bearing, etc., were fully corroborated. I not only visited the original tree, but others within a radius of six miles that had been propagated by grafts, ranging in age from six to fifty-eight years, a11 showing the same characteristics of health, vigor, vitality and general appearance. I was especially particular to notice as to any signs of blights, but failed to detect the slightest trace of it on any of the trees, old or oung.

This fact, to me, is one of the most ralu ${ }^{2}$ ble and important items of merit in a pear tree, freedom from the greatest curse and bane to pear culture-blight. If the quality of the fruit is as represented, this pear will be a valuable acquisition to western horticulture. I hope it will be disseminated as speedily as possible and given a trial throughout the west. I sha11 want

$\begin{array}{lr}\text { and given a tria1 throughout the west. I sha11 want } & \text { Yours truly, } \\ \text { some of the trees for our trial stations. } & \text { G. BRAckEtT. }\end{array}$

Not the slightest trace of blight.

(Co1. Brackett was late secretary, and now rice-president of the American Pomological Society; was also superintendent of Horticulture Department at the New Orleans Exposition, and chief of the Pomological Department at the Centennial Exposition; was commissioner to the Paris Exposition in 1878, and superintendent of the U. S. Pomological division of the Department of Agriculture at the World's Columbian Exposition at Chicago, and judge in the Department of Horticulture.) 


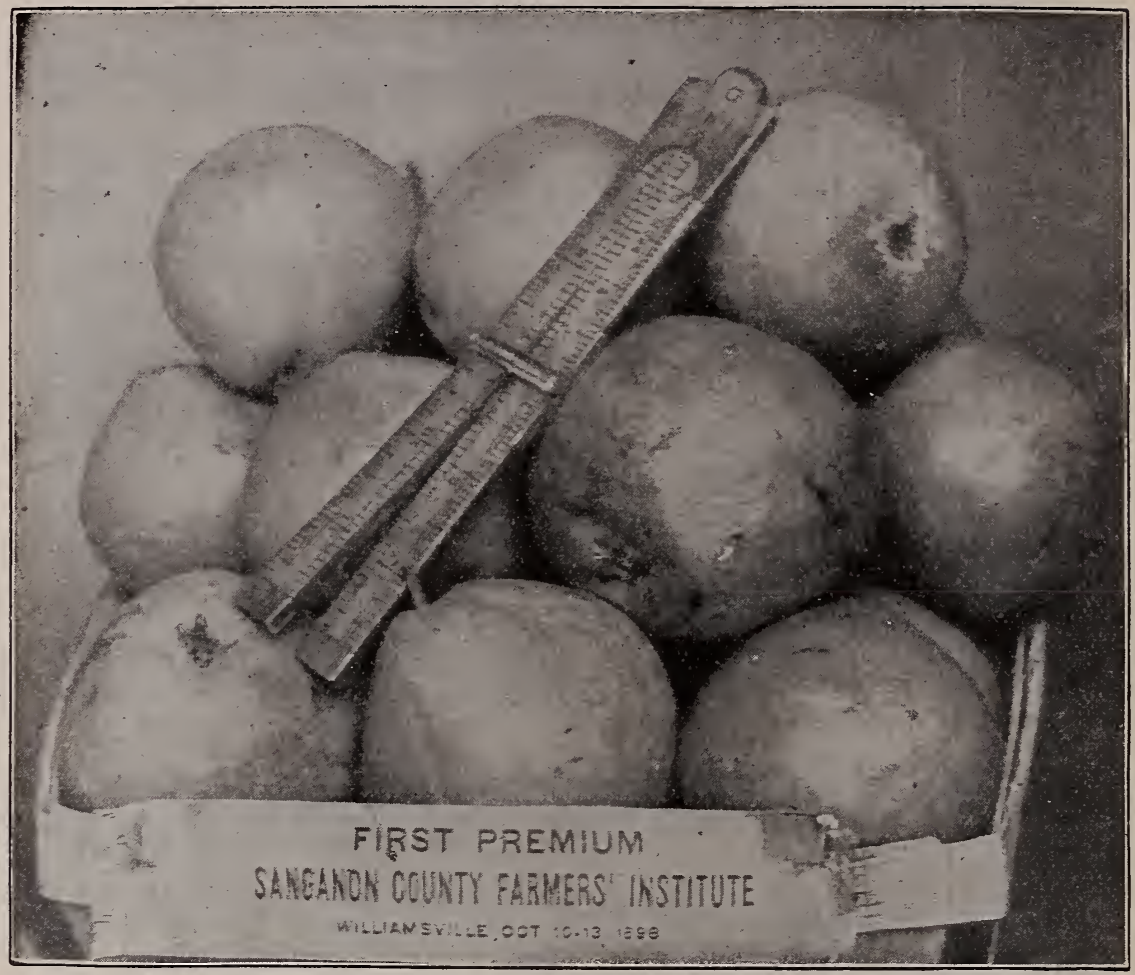

\section{Augustine \& Co.'s Statement.}

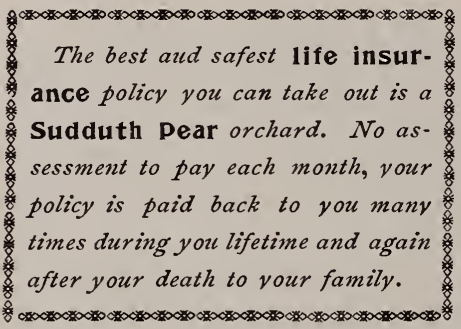

We do not claim that the Sudduth Pear wi11 never blight, that the tree will bear every year in the future, that the fruit will always be seedless and without core, as the future is known only to the Infinite, but we have simply given in our complete booklet that we send out free on application, what the trees have done and are doing now, and have backed these facts up by statements from men of nationa1 reputation which cannot be doubted by reasonable and intelligent people. We believe we have discovered the wonder of the age in horticulture, and unhesitating1y offer it to the public as such. To any who are still skeptical, if they desire it, we can furnish additional testimonials, as we have plenty more in reserve, or what is better sti11, we invite you to come and visit the trees at 'Normal or Williamsville.

Below is a fac simile of our seal and registered trade mark that is placed on every Sudduth Pear tree. It is made of a circular piece of lead about the size of a nickel, and attacbed to the tree by a sma11 twisted wire. It has "Sudduth Pear" and the cut of the pear on one side, and our name and address on the other.

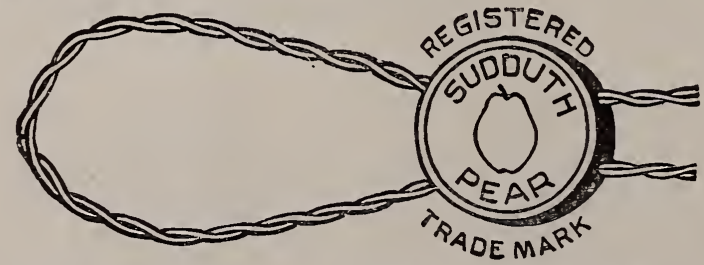

We cannot CAUTION the public too strongly on watching for this seal on every Sudduth pear treeithey receive. The enormous demand that has been created for the 


\section{Our Specialty-The Sudduth Pear.-Continued.}

Sudduth Pear since its introduction has tempted a number of the unscrupulous tree men to sell Sudduth Pears and fill their orders with common varieties. We will give a reasonable reward to any one furnishing us sufficient information for the conviction of any party doing such fraudulent work.

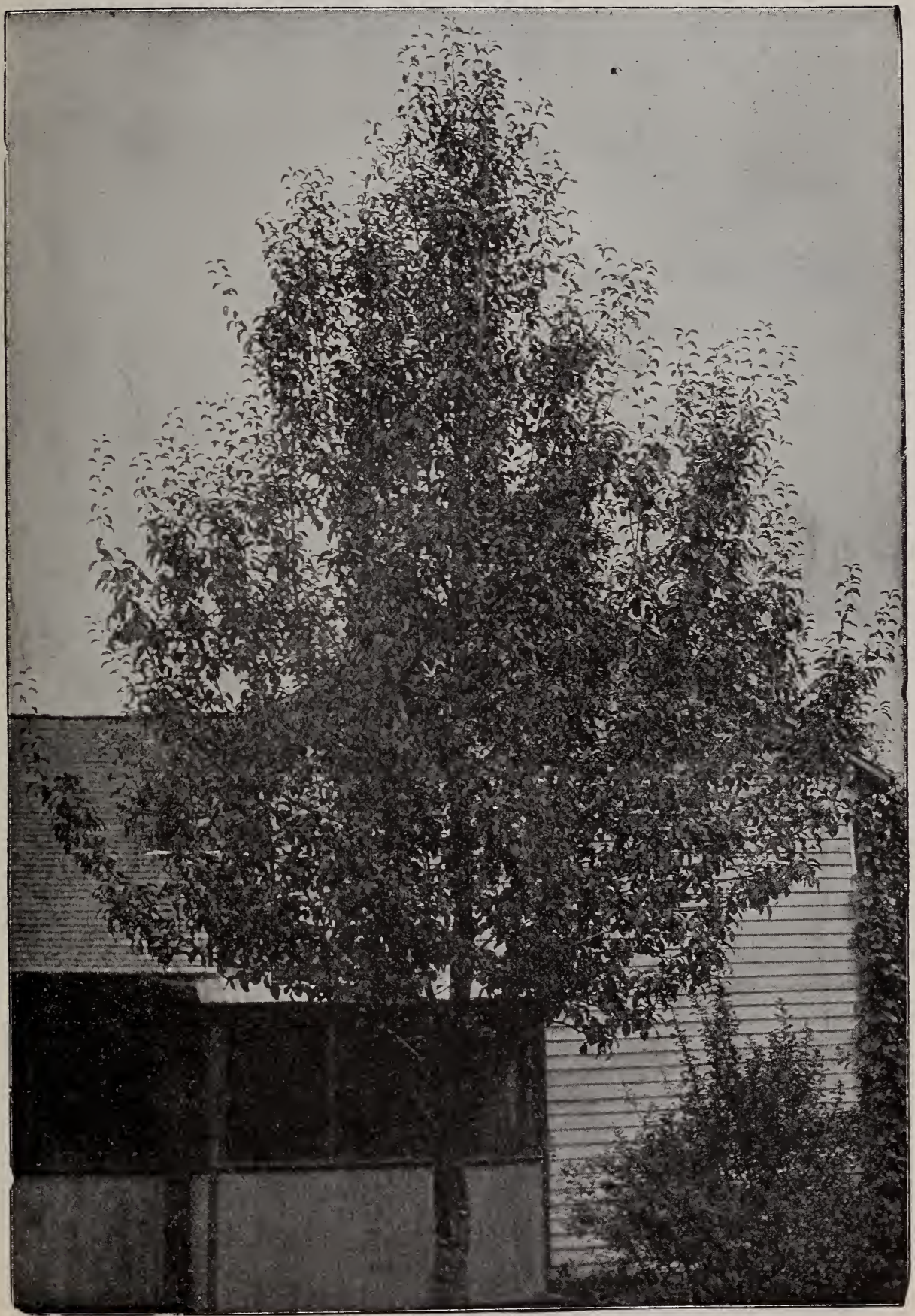


We have published an illustrated history and description of this pear in the shape of a handsome two-color booklet which we shall send free to all who ask for it.

Agents Wanted to sell the

Libera1 terms SUDDUTH to Reliable us. PEAR,
Men. Write us.

\section{Augustine \& $\mathrm{CO}_{\text {, }}$}

.. NURSERYMEN..

Normal, Illinois.

On the opposite page the reader will find a map of the state showing our superior location and the location of Williamsville, the home of the Sudduth Pear.

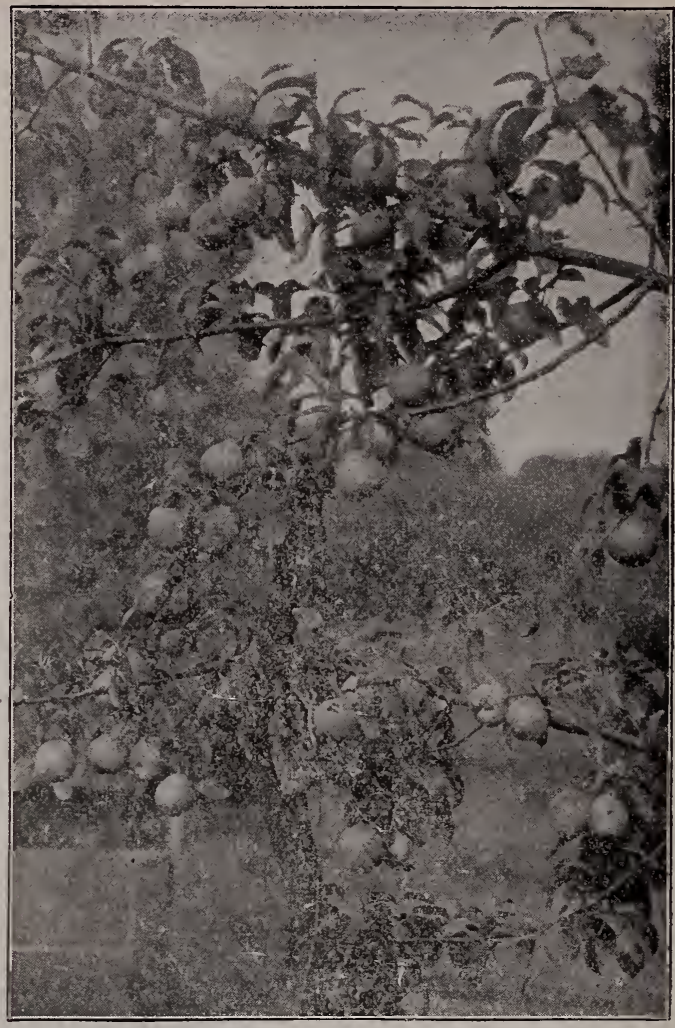

A Sectional View of a Seven-year-old Sudduth Pear Tree.

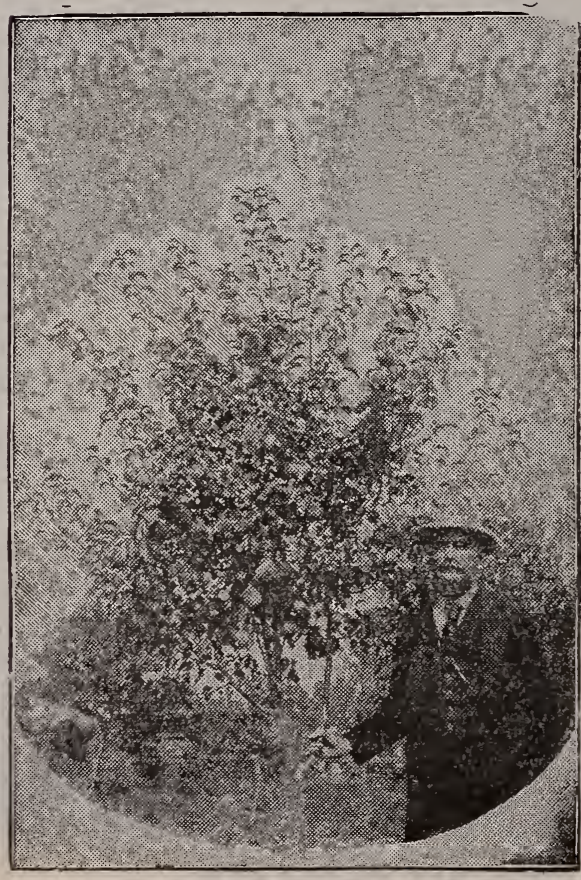

I hereby certify that the photograph of this Sudduth Pear tree, myself standing under it, is a true likeness of the tree I purchased from Augustine \& Co., Normal, I11., in the springof 1896 , being one year old from the graft. The tree is growing on my farm at Flanagan, I11.

Photograph taken in August, 1898.

[SEAL] JOHN DILLON.

Subscribed and sworn to before me this 16th day of January, 1899.

[SEAL] C. C. STUdLEY, J. P. LATER.

Both of my Sudduth Pear trees, planted four years ago this spring, are bearing fruit this year. The one in the photograph has 300 or 400 pears on it now. I would not take $\$ 100$ each for my two trees. I never saw two prettier trees. JOHN DILLON, June 1, 1900. Flanagan, I11. 


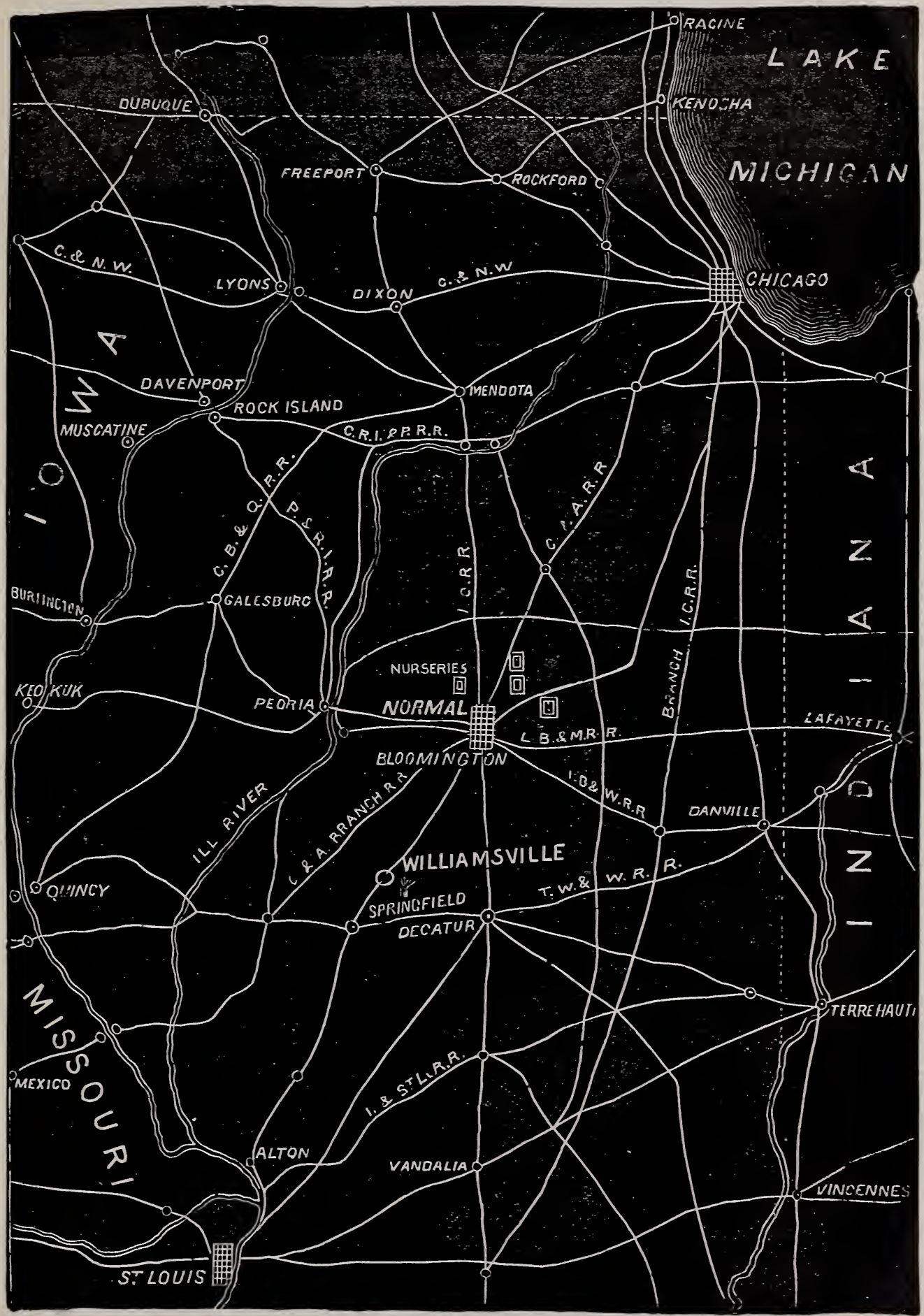

SCALE 95 MILES TI $1 \mathrm{MM}$

Location of Augustine \& Co. showing their superior shipping facilities. 


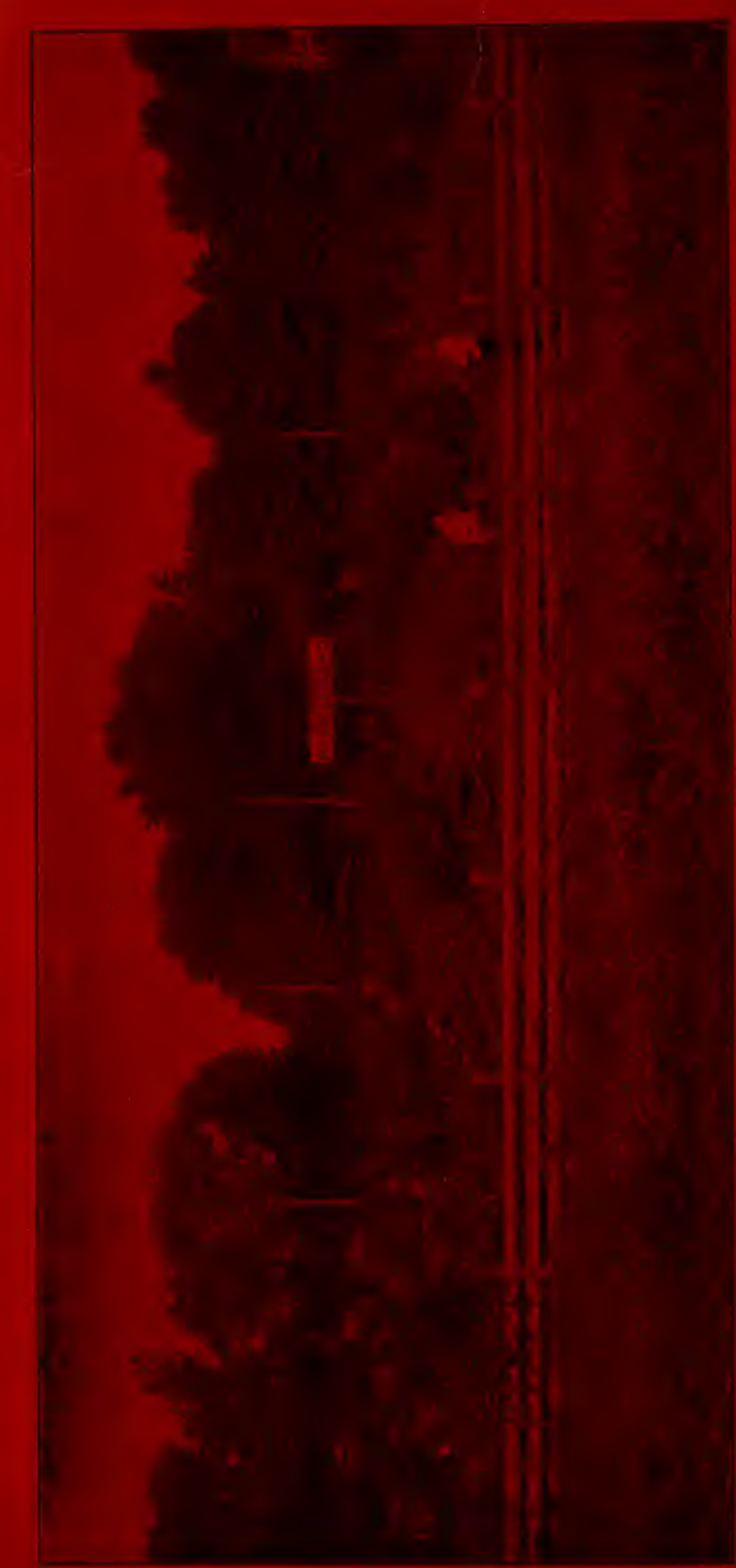

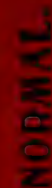

$\frac{1}{0}$

E

$\frac{\Upsilon}{2}$

a

Ш $\infty$

$\cup$

$\frac{7}{41}$

옹

in

a

$=3$

a)

v

Z

$a$

0.

방

료

$\underline{1}$

0

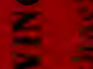

3

逭

$n=$

눈

단둔

보

도

-

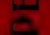

$=\frac{1}{0}$

E

a

웅

(n)

ก

N

12

욤

3

I

흘 